


\title{
Gender Gaps in the Effects of Childhood Family Environment: Do They Persist into Adulthood?
}

\author{
Anne Ardila Brenøe $\mathrm{e}^{\mathrm{a}, *}$ and Shelly Lundberg ${ }^{\mathrm{b}}$
}

October 20, 2016

\author{
${ }^{\text {a }}$ University of Copenhagen, Department of Economics, \\ Øster Farimagsgade 5, Building 26, 1353 Copenhagen K, Denmark, aab@econ.ku.dk \\ b University of California, Santa Barbara, Department of Economics, \\ North Hall 2042, Santa Barbara, CA 93106-9210, USA, slundberg@ucsb.edu
}

\begin{abstract}
We examine the differential effects of family disadvantage on the education and adult labor market outcomes of men and women using high-quality administrative data on the entire population of Denmark born between 1966 and 1995. We link parental education and family structure during childhood to male-female and brother-sister differences in teenage outcomes, educational attainment, and adult earnings and employment. Our results are consistent with U.S. findings that boys benefit more from an advantageous family environment than do girls in terms of the behavior and grade-school outcomes. Father's education, which has not been examined in previous studies, is particularly important for sons. However, we find a very different pattern of parental influence on adult outcomes. The gender gaps in educational attainment, employment, and earnings are increasing in maternal education, benefiting daughters. Paternal education decreases the gender gaps in educational attainment (favoring sons) and labor market outcomes (favoring daughters). We conclude that differences in the behavior of schoolaged boys and girls are a poor proxy for differences in skills that drive longer-term outcomes.
\end{abstract}

JEL classification: I20, J1, J2, J3

Keywords: Gender gap, parental education, family structure, education, labor market outcomes.

${ }^{*}$ Corresponding author. 


\section{Introduction}

Over the past century, the barriers to women's educational and employment opportunities have been dramatically lowered in most of the developed world. Women continue to have lower rates of labor force participation and earn lower pay than men, but new gender gaps that favor women have opened up in education. Young men lag behind young women in academic achievement, and contributing factors include less engagement in school, a gap in homework hours and the substitution of time spent playing video games for time spent reading (OECD, 2015). Women are now more likely than men to complete secondary education and to graduate from college in almost all OECD countries. In the United States, 39 percent of women aged 25 to 29 have a Bachelor's degree or more, compared to 32 percent of men (U.S. Census Bureau, 2015).

Recent studies have focused on the behavioral differences between school-aged boys and girls, arguing that a gender gap in "non-cognitive skills" contributes to the scholastic underperformance of boys by increasing the costs of school persistence and performance (Goldin et al., 2006; Becker et al., 2010). Family disadvantage is strongly negatively associated with early social and behavioral skills for both boys and girls, and it has been suggested that trends in family structure, and in particular the increasing prevalence of single parent families, may have a particularly deleterious effect on the skill development of boys (Bertrand and Pan, 2013; Autor and Wasserman, 2013). If exposure to father absence, povery, or poor neighborhoods harm boys more than girls, then changes in the living arrangements of children over time may explain part of the growing gender gap in educational attainment. Put differently, these recent studies advance the hypothesis that boys benefit more from an advantageous family environment than do girls.

Autor et al. (2016) examine this hypothesis using sibling fixed-effects models and a sample of students in Florida, and find that early family structure and mother's education do have significantly larger effects on a variety of school outcomes for boys than for their sisters. However, there is also evidence that the greater impact of family 
background on boys is most relevant for school-age behavior in the United States, and does not extend to longer-term outcomes such as educational attainment (Lundberg, 2016). With our analysis, we contribute to this literature in three important ways. First, we re-examine and confirm gender differences in the impacts of family environment on school-age outcomes for Denmark, another OECD country with different social institutions and lower poverty prevalence, especially among single-parent families. ${ }^{1}$ Second, our main contribution is to examine a broad range of adult outcomes for the total population as well as for large samples of full siblings. Third, the richness of the data makes it possible to study potential differences in family environment effects across cohorts. Administrative data on the entire population of Denmark from 1980 to 2011 with cohorts born from 1966 to 1995 enables us to link parental education and family structure during childhood to male-female differences in adolescent outcomes, educational attainment, and adult earnings and employment. A significant advantage of the Danish administrative data is that we are able to add paternal education, which is not available for large subsets of the American samples, to our indicators of family background.

Denmark has experienced trends in relative male and female educational attainment and single-parent households that are similar to those in the U.S., though the educational and labor market environments are distinct. ${ }^{2}$ The more comprehensive social safety net may moderate the impacts of family disadvantage on child outcomes. Though female labor force participation rates in Denmark are high, women are more likely to work part-time than in the U.S. and also more likely to work in the public sector. On the other hand, we expect that any developmental process that renders boys more vulnerable to adverse family environments should be a very general one that is manifest in diverse institutional environments. For instance, Landers $\varnothing$ and Heckman (2016) find that despite great social policy differences, the influence of family background on educational attainment is similar in Denmark and the U.S.

\footnotetext{
${ }^{1}$ See e.g. Rossin-Slater and Wüst (2014) on child support obligations in Denmark.

${ }^{2}$ Appendix Figure A1 illustrates the reversal in the gender gap in highest completed education by age 29 for Denmark.
} 
We find, as do Autor et al. (2016) and Lundberg (2016), that adolescent boys appear to be more sensitive than girls to family environment. However, we find a very different pattern of parental influence on adult outcomes such as educational attainment, college graduation, employment, and earnings. Gender differences in the effects of family structure are weak and when we do find significant differential effects they show greater responsiveness for women. Maternal education consistently has a greater impact on the education and employment of daughters relative to sons and this effect is stable across cohorts. Paternal education has some significant, though smaller, effects on the gender education gap that favor sons (and that decline over time), but has larger positive effects on the employment and earnings of daughters. Estimates based on the total population are similar to those obtained from a sample of full siblings controlling for family fixed effects. This suggests that the selection of boys and girls across different family types is not biasing our estimates of the gender gap in the effects of family environment in the full sample.

We conclude that, although there are gender differences in responses to parental resources and family structure, they do not conform to the simple story that the skill development of boys is particularly vulnerable to family disadvantage. Nor is there any evidence, in the Danish context, that changes in family structure have played any role in the growing education gap in favor of girls. Our results are consistent with an alternative hypothesis in which maternal education and other family resources have a strong moderating effect on behavioral problems in school that are much more typical of boys than girls. These parental influences become less important as the children become adults, and there is no indication that these early behavior gaps imply less longterm skill acquisition by boys, relative to girls. Instead, the determinants of educational attainment include positive effects of same-sex parental education that may reflect rolemodelling. The greater responsiveness, in turn, of women's employment and earnings to parental education than the labor market outcomes of adult men, indicates that female labor market behavior in Denmark is more elastic than men's with respect to early influences. 


\section{Family Background and Child Outcomes: Is There a Gender Dimension?}

Boys begin school with less-developed social and behavioral skills than girls, and these gaps persist through elementary school and explain much of the gender differential in early academic outcomes (DiPrete and Jennings, 2012). Girls consistently receive higher grades, are less likely to repeat grades or to be placed in special education classes, and are less likely to get in trouble at school. There are clear behavioral patterns underlying these disparate outcomes - girls spend more time on homework, are more likely to read for pleasure, and exhibit a greater degree of self-discipline in school. ${ }^{3}$ Attempts to explain the emergence of a gender gap favoring women in college attendance and completion have appealed to these gender differences in academic achievement and school discipline as evidence of a "non-cognitive skill" deficit that increases the effective costs of attending and succeeding in school for boys (Goldin et al., 2006; Becker et al., 2010).

In addition to this gender skill gap, there are also strong socioeconomic gradients in early social skills, attention, and school engagement. These skill differences can explain a portion of the socioeconomic differences in young adult outcomes such as arrests and high school completion (Duncan and Magnuson, 2011). Autor and Wasserman (2013) suggest a new explanation for the trend in the relative educational attainment of men and women based on these socioeconomic skill differentials and trends in family structure. They hypothesize that, as the prevalence of single parent families has increased in the U.S. (and elsewhere), economic stresses have increased for children in lower income households and their access to paternal time and attention has decreased. If the skill development of boys is affected more by father absence or family disadvantage than the skill development of girls, then changes in the living arrangements of children over time may play a role in the growing education gender gap. Bertrand and Pan (2013)

\footnotetext{
${ }^{3}$ Duckworth and Seligman (2006) use several measures of self-discipline to document this gender difference, including self-reports, teacher and parent reports, and a delay of gratification test.
} 
provide supportive empirical evidence, showing that living with a single mother or a young mother has a much larger effect on externalizing behavior and school suspensions for boys than for girls. They interpret the negative behavioral impact of father absence and young mothers as evidence that the non-cognitive skills development of boys is particularly sensitive to family disadvantage.

It is not clear what the mechanisms might be that make boys more vulnerable to adverse environments in childhood. One possibility is that gender differences in developmental trajectories may make girls, who enter school more mature in language skills and emotional regulation, inherently more resilient to disadvantage. Alternatively, there may be socioeconomic differences in the way that parents invest in young boys and girls. Baker and Milligan (2013) find that parents in three countries, including the U.S., spend more time in teaching activities with girls than with boys at very young ages. Bertrand and Pan (2013) find that single mothers spend more time with daughters than with sons and report less emotional closeness with sons. Finally, there may be cultural factors that lead boys, in particular, to develop negative attitudes to school in low income or single parent families or that inhibit the educational aspirations of boys relative to girls (DiPrete and Buchmann, 2013). Fortin et al. (2015) find that much of the gender divergence in high school GPA distributions can be attributed to the increasingly ambitious post-school plans of girls relative to boys.

Autor et al. (2016) re-examine this "vulnerable boys" hypothesis using data for a large sample of children in Florida that links birth certificates with academic and health records. Using a variety of measures of family environment (including mother's education, marital status at birth, father presence, and an SES index), neighborhood income and school quality, they find that early family structure and mother's education do have significantly larger effects on a variety of school outcomes for boys than for their sisters, including school suspensions and absences, in both OLS and family fixed effects. There is a larger payoff for boys to having a college graduate mother for a broad set of academic outcomes, including kindergarten readiness and grades. They find similar patterns of differential gender impacts of low-income neighborhoods and poor-quality 
schools, and conclude that family disadvantage has larger impacts on the outcomes of boys relative to girls throughout school. Though they are unable to examine later outcomes, including college attainment, earnings, and labor force participation, Autor et al. (2016) suggest that early gender differences in behavioral and school outcomes are likely to have implications for adult outcomes.

Other studies cast some doubt on this final speculation, however. Riphahn and Schwientek (2015) examine the growth of the gender education gap in Germany, and find that the reversal of this gap has been most pronounced in disadvantaged groups. However, they find no link between family background and gender differences in educational attainment in the individual data. Lundberg (2016), using the National Longitudinal Study of Adolescent to Adult Health (Add Health), finds that father absence is associated with more negative outcomes for school-age boys when the measures are similar to those used in previous studies - problems in school and school suspensions. Girls, on the other hand, are more likely to score higher on indicators of depression when their father is absent, and particularly when they are in a stepfather household. Differential vulnerability to father absence appears to depend on whether the outcomes are related to externalizing behavior, which is more typical for boys, or internalizing behavior, which is a more common response to stress for girls. Lundberg (2016) finds that neither of these patterns of adolescent response have any significant implications for educational outcomes, however: father absence has no differential impact on college graduation in cross-sectional or sibling fixed-effects models. The effects of school quality follow a similar pattern: the gender gap in suspensions and educational aspirations is higher in low quality schools than in high quality schools, but there is no differential gender impact of school quality on educational attainment. ${ }^{4}$

Consequently, it is not clear whether gender differences in the effects of childhood environment persist into adulthood. Using Danish administrative data, we will test

\footnotetext{
${ }^{4}$ Fan et al. (2015) take a different approach to the emerging gender gap, postulating that boys may be more adversely affected by mother's employment in childhood. They find evidence for a more positive association between mother's work and girl's education in Norwegian administrative data using family fixedeffect models. They do not, however, control for mother's education, which we find is a stronger predictor of daughters' outcomes than of sons'.
} 
the hypothesis that males benefit more from mother's and father's education and from having married parents at birth than do females in terms of adult outcomes. For outcomes with a gender gap favoring women, the relevant hypothesis is that the gender gap is smaller for individuals from advantageous family backgrounds. We also test whether any differential effects of family disadvantage by gender have varied across cohorts in ways that could explain trends in the gender gap in education.

\section{Data}

We use Danish administrative data covering the entire population born in Denmark between 1966 and 1995 to examine both outcomes during adolescence and the longer-term consequences of parental resources and family structure in early life. One important feature of this dataset is that we are able to link each child to his or her biological parents (both mother and father) and siblings. Moreover, we observe educational and labor market outcomes for each year, and can track with whom each individual lives.

\subsection{Family Childhood Environment}

We measure three dimensions of childhood family environment: parental education, marital status at birth, and immigrant status. In the administrative data, we observe the father's as well as the mother's education for almost all children, and are able to track family structure from birth through childhood.

We group each parent's education into three categories: less than 12 years of education $(<H S)$ corresponding to high school dropouts in the U.S.; high school graduate $(H S)$ which may include some vocational training or 2 year college; and bachelor's degree graduate or more $(B A)$ corresponding to a degree from a four year college in the U.S. The latter category covers professional bachelor degrees (e.g. school teacher, nursing, physiotherapist, social worker) as well as university and business school degrees.

Our primary measure of family structure is parental marital status at birth. For 
models using our sample of full siblings, we use parents' marital status at the birth of the youngest of their joint children. We choose this alternative definition of marital status because it is very common in Denmark to marry after the birth of the first child and eventual marital status seems to provide a better indicator of the parental relationship as shared by siblings. As almost all parents with more than one child are either married or cohabiting at the time of the youngest of their joint children, we only distinguish between having married and non-married parents. ${ }^{5}$.

For the models of adult outcomes we consider family structure measured at age 12 as well as parental marital status at birth. ${ }^{6}$ For childhood family structure, we distinguish between three types: traditional families where children live with both biological parents (Trad), with no distinction between married and cohabiting parents; step-families in which children live with one biological parent and a step-parent (Step); and single parent families (Single). Using childhood family structure, though it may be endogenous with respect to child outcomes, allows us to include birth cohorts going back to 1966, while marital status at birth is observed only in the medical birth registry which begins in 1973. Family structure at birth and at age 12 are strongly correlated, ${ }^{7}$ and results using both measures are quantitatively similar.

Finally, we consider the immigrant background of both parents separately. The composition of immigrants to Denmark has changed considerably over time. For our earliest cohorts, immigration flows are small and mainly from Western countries (predominantly other Scandinavian countries, Germany, Great Britain, and the U.S.). ${ }^{8}$ Later, immigration expanded to include guest workers and refugees from non-Western countries (with the majority from Turkey, Pakistan, Lebanon, Iraq, and former Yu-

\footnotetext{
${ }^{5}$ Less than two percent of the sibling sample have parents who never cohabit and who are never married at any of the childbirths

${ }^{6}$ More precisely, family structure at age 12 is measured on January $1^{\text {st }}$ of the year the child turns 13 . We also considered family structure at age 16 with very similar results.

${ }^{7}$ Of those last born children who were born to married (non-married) parents, 80.88 (60.69) percent live in a traditional family at age 12, while 7.48 (14.46) percent live in a step family and 11.64 (24.85) percent live with a single parent.

${ }^{8}$ Statistics Denmark defines "Western" countries as European Union countries by 1995, Andorra, Australia, Canada, Iceland, Liechtenstein, Monaco, New Zealand, Norway, San Marino, Switzerland, USA, and Vatican City.
} 
goslavia). Of the cohort born in 1966, 3.2 (2.6) percent have an immigrant mother (father) of whom 64.4 (54.4) percent originate from a Western country. For the last birth cohort in our sample (born in 1995), 13.8 (13.6) percent have an immigrant mother (father) of whom only 20.1 (22.8) percent come from a Western country.

\subsection{Outcome Variables: From Adolescence through Adult- hood}

The outcomes of interest fall into two groups: 1) School and behavioral outcomes measured in adolescence and 2) Educational attainment and labor market outcomes, primarily measured at age 27 . Since these outcomes span from age 16 through age 27 (and in some specifications through age 40) and come from several administrative registers, different birth cohorts will be used in analyses of outcomes in adolescence and adulthood; Appendix Table A1 summarizes the cohorts used for each part of the analysis. ${ }^{9}$ We have one outcome that is available for all cohorts, completion of grade 9 on time, and we use this outcome to examine whether the gender gap in the effects of family environment has changed over time.

In Denmark, the first nine years of schooling constitute primary school and are mandatory. Children are required to start first grade the year they turn 7 , though parents are able to apply for an exemption such that their child starts school a year earlier or later. Boys are about twice as likely to delay school start compared to girls (Dee and Sievertsen, 2015). Grade repetition is very rare; Simonsen et al. (2015) show that on average less than 0.5 percent are retained or delayed for each grade level from grade 1 to 9 . Whether the child completes grade 9 on time is a marker of academic achievement that reflects a combination of early school readiness and success in school progression, and is strongly correlated with final educational attainment.

At the end of primary school, students take the final grade 9 exam, which is the

\footnotetext{
${ }^{9}$ When we refer to outcomes at a certain age, we always refer to the age the individual turns during the particular year. Thus, grade 9 outcomes are measured at age 15 for about half of the sample, since the school year ends in June.
} 
same across the country and is required for all students who continue to academic high school. ${ }^{10}$ Our second school outcome is the overall GPA obtained at the end of grade 9 (based on all grades received both from teacher assessment and final exams). ${ }^{11}$ Other early outcomes include indicators of having received a diagnosis for behavioral and emotional disorders at a hospital ${ }^{12}$ and attending special education during grade $9{ }^{13}$ Since the administrative data on grade 9 GPA begins in 2002, we consider birth cohorts born from 1986 to 1995 for this part of the analysis.

After primary school, students can choose to continue to academic high school, which takes three years, or vocational training programs of differing lengths (predominantly 13 or 13.5 years). A diploma from the academic high school is necessary to apply for university. A bachelor's degree from university takes three years (i.e. 15 years of completed education) and a master's degree takes two additional years. Instead of university, it is possible for academic high school graduates to take a two year college degree or to enter vocational training.

Figure 1 shows the share of people who have completed certain levels of education at each age from 15 to 30 years. This indicates that by age 27 almost everyone has completed their education, and we study educational attainment and labor market outcomes at this age. Educational attainment is measured as highest completed education measured in months or, alternatively, having a BA degree or more. In terms of labor market outcomes, we consider whether the person is employed and, for wage earners, the annual labor earnings percentile by year of birth and gender. ${ }^{14}$ For the primary

\footnotetext{
${ }^{10}$ Since 2007, the exam has been mandatory for all students.

${ }^{11}$ Similar results are found if we instead only use the GPA from written national exams in Math and Danish. If we consider the test scores from these exams separately, the differential effects are mainly found for Danish.

${ }^{12}$ This outcome is defined from hospital records in the Danish national patient registry and is based on both inpatient and outpatient hospital records. For the definition of behavioral and emotional disorders with onset usually occurring in childhood and adolescence, we use the International Classification of Diseases (ICD) version 10 from 1994-2012 (diagnosis codes F90-98). We require that the person has received at least one of these diagnoses by age 21; 92 percent of those with a diagnosis by age 21 have received it by age 16 . This measure will be incomplete, since psychiatrists working outside the hospital system do not report to the registry; see the discussion in Obel et al. (2015).

${ }^{13}$ Special education is only observed for 2007-2011.

${ }^{14}$ Individuals are defined as being employed if they have any positive labor earnings or have employment as the main source of income, including self-employment. The results are very similar if we alternatively
} 


\section{Figure 1}

Educational Attainment in Denmark by Age

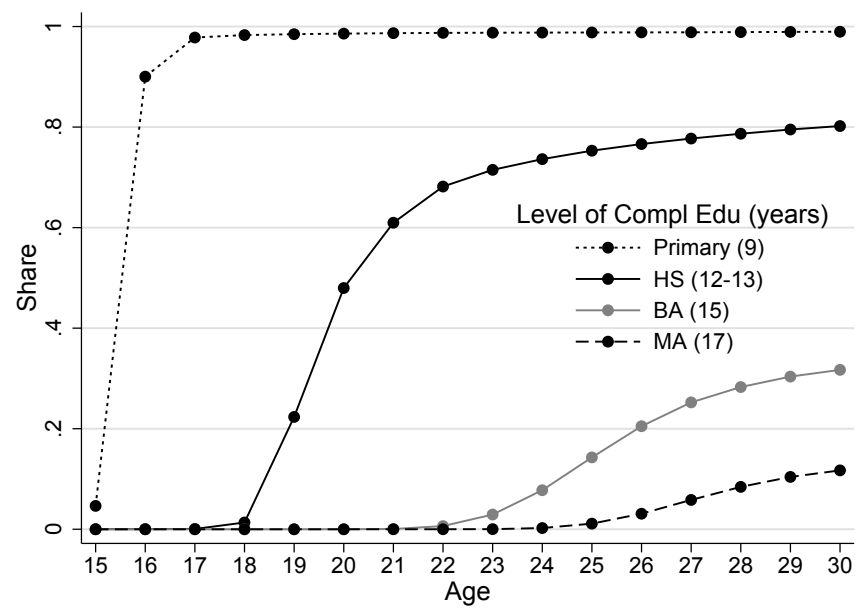

Note: Share of individuals (birth cohorts 1973-1984) with the specified educational level or more to each age from 15-30 years. The category $H S$ covers academic high school and vocational training with a length of at least 12 years.

analysis of adult outcomes, the sample consists of individuals born between 1973 and 1984, for whom we can observe both parents' marital status at birth and outcomes at age $27 . .^{15}$

\section{Sample Selection and Empirical Framework}

\subsection{Summary Statistics}

So that we observe the family environment during childhood as well as adult outcomes, we consider individuals born between 1973 and 1995 for the main analysis; for the analysis of educational attainment across cohorts, we include cohorts going back to 1966. We restrict the sample to those for whom we observe all parental variables ${ }^{16}$

define individuals as being employed if their main source of income comes from employment (including self-employment) or if they have wage earnings exceeding 55.000 DKK in 2011 prices (corresponding to approximately 9600 USD with the exchange rate measured per December 31, 2011). The measure of earnings is the total sum of income earned from wage employment during a particular year.

${ }^{15}$ When we examine whether the gender gaps in family effects have changed over time, we expand the sample to cohorts born between 1966 and 1984.

${ }^{16}$ Since parental education is a key variable for the analysis, we restrict the sample to those families where we observe both parents' education. Mother's (father's) education is missing for 1.8 (2.9) percent of children 
Table 1

Sample Selection: Averages of Family Environment (Percent)

\begin{tabular}{|c|c|c|c|}
\hline Samples & $\begin{array}{c}\text { a) Entire } \\
\text { Population }\end{array}$ & $\begin{array}{l}\text { b) Total Pop for } \\
\text { Estimation }\end{array}$ & $\begin{array}{l}\text { c) Sibling } \\
\text { Sample }\end{array}$ \\
\hline \multicolumn{4}{|c|}{ Selection Criteria and Background Information } \\
\hline Child is male & 51.23 & 51.27 & 51.37 \\
\hline Child's year of birth & 1984 & 1984 & 1984 \\
\hline Child is twin & 2.28 & 0.00 & 0.00 \\
\hline Child is adopted & 0.90 & 0.00 & 0.00 \\
\hline \# of Children in Family & 2.60 & 2.55 & 2.73 \\
\hline Child's birth order & 1.80 & 1.78 & 1.84 \\
\hline Mother's age at birth (years) & 27.04 & 27.12 & 26.97 \\
\hline Mother's age missing & 1.26 & 0.00 & 0.00 \\
\hline Marital status missing & 6.39 & 0.00 & 0.00 \\
\hline Father is unknown & 3.22 & 0.00 & 0.00 \\
\hline Mother edu missing & 4.01 & 0.00 & 0.00 \\
\hline Father edu missing & 7.34 & 0.00 & 0.00 \\
\hline \multicolumn{4}{|l|}{ Parental Education } \\
\hline Mother $<$ HS & 34.84 & 34.33 & 32.80 \\
\hline Mother HS & 38.48 & 38.63 & 38.46 \\
\hline Mother BA & 26.68 & 27.04 & 28.74 \\
\hline Father $<$ HS & 26.90 & 26.65 & 25.11 \\
\hline Father HS & 52.84 & 53.18 & 53.62 \\
\hline Father BA & 20.26 & 20.17 & 21.26 \\
\hline \multicolumn{4}{|c|}{ Marital Status and Immigrant Background } \\
\hline Married at own birth & 63.11 & 63.45 & 67.96 \\
\hline Married at youngest sib birth & 70.68 & 71.47 & 79.43 \\
\hline Mother immigrant & 10.61 & 5.46 & 6.16 \\
\hline Mother Western immigrant & 2.66 & 1.52 & 1.51 \\
\hline Father immigrant & 10.00 & 5.91 & 6.52 \\
\hline Father Western immigrant & 2.53 & 1.66 & 1.61 \\
\hline \multicolumn{4}{|c|}{ Family Structure at Youngest Sib Age 12 (Cohorts 1973-84) } \\
\hline Traditional family & 69.40 & 75.35 & 80.76 \\
\hline Step-parent family & 9.31 & 9.76 & 6.96 \\
\hline Single-parent family & 21.29 & 14.89 & 12.28 \\
\hline $\mathrm{N}$ & $1,534,596$ & $1,300,453$ & 898,933 \\
\hline
\end{tabular}

The columns represent three different samples of individuals born between 1973 and 1995: a) the entire population; b) the total population for estimation of Grade 9 completion on time (i.e. individuals who are not twins or adoptees and have an observation on all parental variables); and c) the sibling sample with an observation on Grade 9 completion on time (i.e. those who are observed in (b) and have at least one biological sibling in the sample). Note that the following variables are not reported as percent: year of birth, \# of children in family, and birth order. 
and include only families without adopted children and only singleton births. ${ }^{17}$ For the main analysis, we consider this sample (referred to as the total population) as well as the subsample of families with at least two full siblings (i.e. children with the same mother and same father; referred to as the sibling sample).

\section{Figure 2}

Gender Gap in Highest Completed Education (in Months) at 27



(a) By Maternal Education



(b) By Family Structure

Note: Male-female gap in highest completed education at age 27 by maternal education and family structure at age 12, respectively. The gap is calculated as the difference between the raw mean for each gender by birth cohort for the total population.

Table 1 provides descriptive statistics for three different samples of individuals born between 1973 and 1995: a) the entire population; b) the total population sample for the estimation of Grade 9 completion on time; and c) the sibling sample with an observation on Grade 9 completion on time. The largest differences between the sibling sample and the other two samples are that, on average, children in the former sample have slightly better educated parents, parents more likely to be married at birth, and fewer parents with an immigrant background. ${ }^{18}$

who would otherwise have been in the sibling sample. Results from models including only mother's education are not sensitive to excluding or including the children without information on father's education.

${ }^{17}$ However, as a robustness check, we have also estimated the core models in a sample of gender-discordant twins and get consistent results.

${ }^{18}$ Some children of immigrant parents are immigrants themselves and therefore not observed at birth. The primary reason for a missing observation on marital status at birth is because the child is not observed in the birth registry (i.e. is born outside Denmark). 
Figure 2 shows the raw gender gap in educational attainment at age 27 by childhood family environment. ${ }^{19}$ Educational attainment was equal for men and women born in the first period (1966-1970). For subsequent cohorts, the gender gap has increased such that women born between 1979 and 1984 have attained about five months more education by age 27 than their male counterparts on average. The educational gender gap is smallest for the children of less-educated mothers. In contrast, there is little variation in the gender gap by family structure.

\subsection{Empirical Framework}

Our goal is to identify whether childhood family environment has a differential impact on men's relative to women's adult outcomes to test the "vulnerable boys" hypothesis. The empirical strategy is twofold: First, we compare the male-female differences in adolescence and adult outcomes by family environment (i.e. a difference-in-difference strategy). Second, we focus on differences between brothers and sisters with the same mother and father by family characteristics (i.e. controlling for family fixed effects).

We begin by estimating an OLS model of the effect of family environment on outcomes for boys and girls using the total population sample. The outcome $Y$ of individual $i$ in family $j$ exposed to the family environment, Fam Env, is given by:

$$
Y_{i j}=\beta_{0}+\beta_{1} \text { Male }_{i}+\beta_{2} \text { Fam Env }_{i}+\beta_{3} \text { Male }_{i} \times \text { Fam Env }_{i}+X_{i}^{\prime} \theta+\nu_{i j}
$$

where $X_{i}$ is a vector of individual controls (year and month of birth, birth order, mother's age at birth, family size $)^{20}$ and standard errors, $\nu_{i j}$, are clustered at the family level. For the estimation, we exploit the randomness in child gender; as long as child gender is independent of family environment, $\beta_{3}$ represents the causal effect of family environment on gender differences in adult outcomes.

\footnotetext{
${ }^{19}$ The raw gender gap by paternal education is very similar to the one observed in Figure 2; the gender gap for the sibling sample is similar as well.

${ }^{20}$ For the adult outcomes, we also include a control for whether the outcome is measured one year later or earlier, e.g. at age 28 or 26 instead of age 27 .
} 
However, these estimates may be biased if family structure and child gender are not independent. Sex-selective abortion, which might generate a correlation between marital status and child gender, is not expected to be an important consideration in the Danish context, but there is considerable evidence from a number of countries that fathers are more likely to co-reside with, seek custody of, and marry the mothers of their sons rather than daughters (Lundberg and Rose, 2003; Dahl and Moretti, 2008; Lundberg, 2005). There is also increasing evidence that the Trivers-Willard hypothesis, which suggests that females in advantaged circumstances are more likely to bear male offspring, may apply to human populations through the impact of stress on the mortality of male and female fetuses (Almond and Edlund, 2007; Hamoudi and Nobles, 2014; Norberg, 2004; Trivers and Willard, 1973); though the effects of even extreme events are small. If these factors generate systematic selection of boys and girls across family types, cross-sectional models of the effects of family environment will be misleading.

To consider whether selection into specific family types by gender might be a problem, Table 2 reports the means of the family environment variables for girls and boys separately and tests whether we can reject that these means are equal [Columns (1) to (3)]. There are few significant differences, even with these large samples: at a five percent level, we can reject that fathers of boys and girls are equally likely to have at least a BA degree and that boys and girls are equally likely to live in a traditional family at age 12 . Columns (4-6) show the same analysis for children from families with only girls and only boys. There are more significant differences, with boys from only-boy families more likely to have parents who are immigrants, married at birth, and live together at age 12 than are girls from only-girl families. These differences suggest that boys and girls are not randomly distributed across different family types, but the differences in means are extremely small.

As an alternative empirical approach, we focus on differences between brothers and 


\section{Table 2}

Comparing Characteristics by Gender and Families with Only Girls or Boys

\begin{tabular}{|c|c|c|c|c|c|c|}
\hline \multirow[t]{2}{*}{ Comparison } & \multicolumn{3}{|c|}{ All Girls vs All Boys } & \multicolumn{3}{|c|}{ Families with only Girls vs Boys } \\
\hline & Girls & Boys & t-test & Girls & Boys & t-test \\
\hline Statistic & $\begin{array}{c}\text { Mean } \\
(1)\end{array}$ & $\begin{array}{l}\text { Mean } \\
(2)\end{array}$ & $\begin{array}{c}\text { P-value } \\
(3)\end{array}$ & $\begin{array}{l}\text { Mean } \\
(4)\end{array}$ & $\begin{array}{l}\text { Mean } \\
(5)\end{array}$ & $\begin{array}{c}\text { P-value } \\
(6)\end{array}$ \\
\hline $\begin{array}{l}\text { \# of Children in Family } \\
\text { Parental Education }\end{array}$ & 2.55 & 2.56 & 0.00 & 2.05 & 2.10 & 0.00 \\
\hline Mother $<\mathrm{HS}$ & 34.33 & 34.33 & 0.94 & 31.67 & 32.05 & 0.00 \\
\hline Mother HS & 38.70 & 38.57 & 0.13 & 41.16 & 40.69 & 0.00 \\
\hline Mother BA & 26.97 & 27.10 & 0.08 & 27.16 & 27.26 & 0.42 \\
\hline Father $<$ HS & 26.69 & 26.61 & 0.29 & 25.04 & 25.28 & 0.04 \\
\hline Father HS & 53.22 & 53.15 & 0.45 & 54.59 & 54.23 & 0.01 \\
\hline Father BA & 20.09 & 20.24 & 0.03 & 20.37 & 20.49 & 0.28 \\
\hline \multicolumn{7}{|c|}{ Marital Status and Immigrant Background } \\
\hline Married at own birth & 63.51 & 63.40 & 0.20 & 60.43 & 60.74 & 0.02 \\
\hline Married at y. sib birth & 71.47 & 71.48 & 0.88 & 67.28 & 67.72 & 0.00 \\
\hline Mother immigrant & 5.48 & 5.43 & 0.24 & 3.81 & 4.21 & 0.00 \\
\hline Father immigrant & 5.94 & 5.89 & 0.24 & 4.24 & 4.60 & 0.00 \\
\hline \multicolumn{7}{|c|}{ Family Structure at Youngest Sib Age 12 (Cohorts 1973-84) } \\
\hline Traditional family & 75.22 & 75.47 & 0.01 & 73.67 & 74.12 & 0.00 \\
\hline Step-parent family & 9.77 & 9.75 & 0.75 & 9.60 & 9.67 & 0.55 \\
\hline Single-parent family & 15.01 & 14.78 & 0.00 & 16.73 & 16.21 & 0.00 \\
\hline $\mathrm{N}$ & 633,753 & 666,700 & $1,300,453$ & 252,864 & 280,376 & 533,240 \\
\hline
\end{tabular}

Columns (1) to (2) compare the means of all girls and all boys for the total population; Column (3) reports the p-value from a t-test of the null-hypothesis that the mean of girls equals the one of boys. Columns (4) to (5) compare the means of children from families with only-girls and families with only-boys for the total population (consequently there is some overlap between the sample in Columns (1) and (4) and Columns (2) and (5)); Column (6) reports the p-value from a t-test of the null-hypothesis that the mean of only-girl families equals the one of only-boy families. The means are reported as percentages except for \# of Children in Family. 
sisters with the same mother and father who were raised in the same household:

$$
Y_{i j}=\alpha_{0}+\alpha_{1} \text { Male }_{i}+\alpha_{2} \text { Male }_{i} \times \text { Fam Env }_{j}+X_{i}^{\prime} \gamma+\mu_{j}+\epsilon_{i j}
$$

where $\mu_{j}$ is a family fixed effect. In this model, $\alpha_{2}$ represents the causal effect of family environment on gender differences in adult outcomes as long as we do not omit any important time-varying variable. ${ }^{21}$ This empirical strategy has drawbacks, however. In addition to cutting the sample size in half, it restricts the sample to families with at least two gender-discordant siblings. If there are behavioral spillovers between siblings, or if patterns of parental investments are different in only-child families or families with same-sex children, then the estimate of $\alpha_{2}$ from the sibling sample may not be representative of the effects of family environment in all families. ${ }^{22}$

To examine whether the gender gaps in the effects of family environment have changed across birth cohorts, we also interact the independent variables of interest with a vector of birth cohort dummies (grouped into intervals), $C$ :

$$
Y_{i j}=\delta_{0}+\left(\text { Male }_{i} \times C_{i}\right)^{\prime} \delta_{1}+\left(\text { Male }_{i} \times \text { Fam Env }_{j} \times C_{i}\right)^{\prime} \delta_{2}+\left(\text { Fam Env }_{j} \times C_{i}\right)^{\prime} \delta_{3}+X_{i}^{\prime} \eta+\mu_{j}+\zeta_{i j}
$$

\footnotetext{
${ }^{21}$ As a robustness check (Appendix Table A6), we restrict the sample to only those full siblings who experience the same observable childhood family structure such that the oldest sibling experiences the same family structure as the youngest.

${ }^{22}$ Interpreting the coefficients $\beta_{3}$ and $\alpha_{2}$ in equations (1) and (2) as indicators of the causal effect of post-natal family environment on child development requires that we assume that parental resources do not affect the endowments of boys and girls at birth differently. Autor et al. (2016) show that this assumption is reasonable for their Florida data; they do not find a sibling gender gap in the effects of family conditions on birth outcomes when controlling for mother fixed effects. In Appendix Table A2, we show that the prenatal inputs and birth outcomes of sisters and brothers are not differently affected by the family environment in the Danish data.
} 


\section{Results}

\subsection{Outcomes in Adolescence}

Table 3 reports key coefficients from the models of Grade 9 outcomes, using both the total population and sibling samples. Column (1) shows that, for the total population, boys are 9.2 percentage points less likely to complete grade 9 on time than girls, conditional on year and month of birth, birth order, maternal age at birth, and family size. ${ }^{23}$ Column (2) adds mother's education, immigrant background, and marital status at birth as well as interaction terms between these variables and a male dummy. Boys benefit more from having a high educated mother (HS and BA degree) compared to girls; the male disadvantage is reduced by 1.0 and 2.0 percentage points for boys of HS and BA educated mothers, respectively. Males also benefit from having an immigrant mother and from being born to married parents. Column (3) adds father's education and highlights one advantage of our data (i.e. that we observe fathers' characteristics for almost all children): the benefit of mother's education for boys diminishes substantially when father's education is included and father's education further reduces the gender gap within families with better educated fathers. For highly educated fathers, the gender gap is reduced by 2.6 percentage points (23 percent compared to children with less than HS educated fathers). Column (4) estimates the same model as in Column (3) but on the sibling sample rather than the total population with very similar point estimates and significance levels. Finally, Column (5) includes family fixed effects for the sibling sample, which again give very similar results compared to using the total population without fixed effects.

The gender gap in grade 9 GPA is large - almost 0.30 of a standard deviation [Column (6)]. The results for this outcome are somewhat different from other adolescent outcomes in that some indicators of parental resources increase, rather than decrease, the gender gap and there are some discrepancies between the results from the total and

\footnotetext{
${ }^{23}$ This number is 8.7 percentage points for the sibling sample without controlling for family fixed effects and 8.9 percentage points with fixed effects, see Columns (3) and (6) in Panel A in Appendix Table A7.
} 
the sibling samples. Paternal college education reduces the gender gap in grade 9 GPA [Columns (8) to (10)]; this is true for all model versions and the effect nearly doubles in the fixed-effect model. However, having married parents at birth increases the gap. Maternal education and father's HS education also increase the gender gap in the OLS estimates, for the total population, but are insignificant in all other models. Overall, differential gender impacts of family advantage do not explain much of the gender gap in grade 9 achievement.

Table 4 examines sibling differences in diagnosis for behavioral and emotional disorder and attending special education during $9^{\text {th }}$ grade. From Columns (1) and (6), it is clear that these outcomes are more prevalent among boys: 63 percent of those with behavioral and emotional problems and 67 percent of those attending special education are male. ${ }^{24}$ The OLS models of behavioral and emotional disorder indicate that higher parental education reduces the gender gap [Columns (2) to (4)] in the total sample. Only father's BA is still significant in the sibling model with fixed effects. However, both maternal and paternal education decrease the probability of attending special education much more for boys than girls [Columns (5) to (6)].

We observe on-time completion of grade 9 consistently across cohorts, and therefore use this outcome to look at whether the gender gap in the effects of family environment has changed over time. Since we examine adult outcomes as well, we want to know whether potential varying effects between childhood and adult outcomes are due to different ages at observation or due to different birth cohorts. For this analysis, we estimate equation (3).

\footnotetext{
${ }^{24}$ Kristoffersen et al. (2015) find a strong association between behavioral problems and school outcomes for Danish children, but the behavioral gender gap explains only a fraction of the gender difference in test scores.
} 
Table 3

Grade 9 On Time and GPA

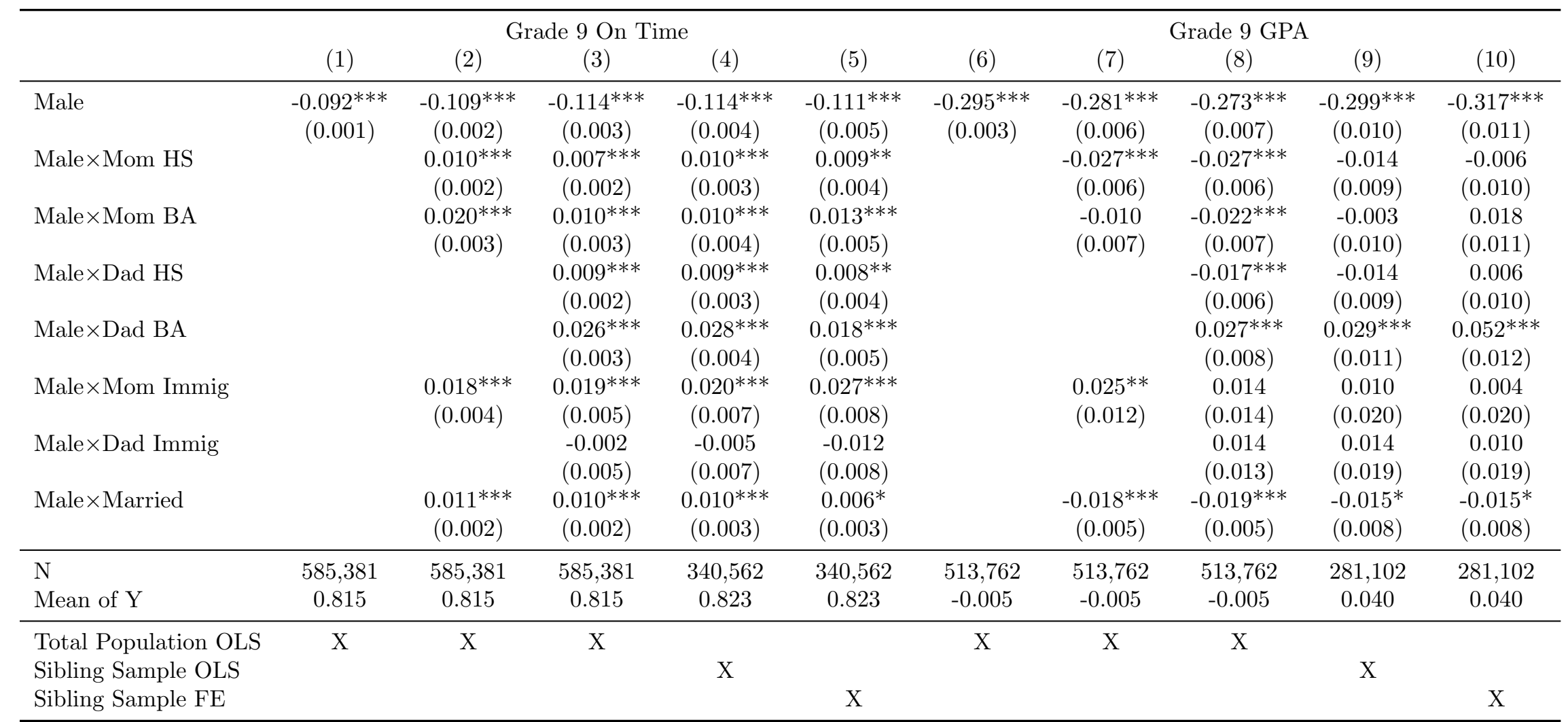

Standard errors in parentheses, clustered at the family level. ${ }^{*} p<0.1,{ }^{* *} p<0.05,{ }^{* * *} p<0.01$. The samples consist of individuals born from 1986-1995. Grade 9 on time indicates whether the person completed grade 9 by age 16 . GPA is an average of all grades given during grade 9 both from teacher assessment and final exams for all subjects and is standardized with mean zero and standard deviation of 1 by year of grade 9 completion for the total population. All models control for year of birth dummies, month of birth dummies, birth order dummies, maternal age at birth (linear, squared, and cubed), and a constant. All OLS models additionally control for family size dummies and those variables of family environment that are interacted with the male dummy, and the FE models control for family fixed effects. 
Table 4

Behavioral \& Emotional Disorder and Special Education

\begin{tabular}{|c|c|c|c|c|c|c|c|c|c|c|}
\hline & \multicolumn{5}{|c|}{ Behavioral \& Emotional Disorder } & \multicolumn{5}{|c|}{ Special Education } \\
\hline & $(1)$ & $(2)$ & $(3)$ & $(4)$ & (5) & (6) & $(7)$ & (8) & (9) & $(10)$ \\
\hline Male & $\begin{array}{c}0.010^{* * *} \\
(0.000)\end{array}$ & $\begin{array}{c}0.012^{* * *} \\
(0.001)\end{array}$ & $\begin{array}{c}0.014^{* * *} \\
(0.001)\end{array}$ & $\begin{array}{c}0.012^{* * *} \\
(0.001)\end{array}$ & $\begin{array}{c}0.012^{* * *} \\
(0.002)\end{array}$ & $\begin{array}{c}0.012^{* * *} \\
(0.001)\end{array}$ & $\begin{array}{c}0.022^{* * *} \\
(0.002)\end{array}$ & $\begin{array}{c}0.028^{* * *} \\
(0.002)\end{array}$ & $\begin{array}{c}0.027^{* * *} \\
(0.003)\end{array}$ & $\begin{array}{c}0.027^{* * *} \\
(0.005)\end{array}$ \\
\hline Male×Mom HS & & $\begin{array}{l}-0.001 \\
(0.001)\end{array}$ & $\begin{array}{c}0.000 \\
(0.001)\end{array}$ & $\begin{array}{c}0.001 \\
(0.001)\end{array}$ & $\begin{array}{l}-0.001 \\
(0.001)\end{array}$ & & $\begin{array}{c}-0.009^{* * *} \\
(0.002)\end{array}$ & $\begin{array}{c}-0.007^{* * *} \\
(0.002)\end{array}$ & $\begin{array}{c}-0.009^{* * *} \\
(0.003)\end{array}$ & $\begin{array}{c}-0.010^{* * *} \\
(0.004)\end{array}$ \\
\hline Male $\times$ Mom BA & & $\begin{array}{c}-0.003^{* * *} \\
(0.001)\end{array}$ & $\begin{array}{c}-0.002^{*} \\
(0.001)\end{array}$ & $\begin{array}{l}-0.001 \\
(0.001)\end{array}$ & $\begin{array}{l}-0.002 \\
(0.002)\end{array}$ & & $\begin{array}{c}-0.014^{* * *} \\
(0.002)\end{array}$ & $\begin{array}{c}-0.010^{* * *} \\
(0.002)\end{array}$ & $\begin{array}{c}-0.009^{* * *} \\
(0.003)\end{array}$ & $\begin{array}{c}-0.011^{* * *} \\
(0.004)\end{array}$ \\
\hline Male×Dad HS & & & $\begin{array}{c}-0.003^{* * *} \\
(0.001)\end{array}$ & $\begin{array}{c}-0.003^{* * *} \\
(0.001)\end{array}$ & $\begin{array}{l}-0.002 \\
(0.002)\end{array}$ & & & $\begin{array}{c}-0.010^{* * *} \\
(0.002)\end{array}$ & $\begin{array}{c}-0.012^{* * *} \\
(0.003)\end{array}$ & $\begin{array}{c}-0.010^{* * *} \\
(0.003)\end{array}$ \\
\hline Male×Dad BA & & & $\begin{array}{c}-0.005^{* * *} \\
(0.001)\end{array}$ & $\begin{array}{c}-0.005^{* * *} \\
(0.001)\end{array}$ & $\begin{array}{c}-0.004^{* *} \\
(0.002)\end{array}$ & & & $\begin{array}{c}-0.013^{* * *} \\
(0.002)\end{array}$ & $\begin{array}{c}-0.016^{* * *} \\
(0.003)\end{array}$ & $\begin{array}{c}-0.014^{* * *} \\
(0.004)\end{array}$ \\
\hline Male $\times$ Mom Immig & & $\begin{array}{c}-0.003^{* *} \\
(0.001)\end{array}$ & $\begin{array}{c}-0.005^{* * *} \\
(0.002)\end{array}$ & $\begin{array}{c}-0.004^{* *} \\
(0.002)\end{array}$ & $\begin{array}{l}-0.004 \\
(0.003)\end{array}$ & & $\begin{array}{c}0.004^{* *} \\
(0.002)\end{array}$ & $\begin{array}{c}0.001 \\
(0.003)\end{array}$ & $\begin{array}{c}0.009^{* *} \\
(0.004)\end{array}$ & $\begin{array}{l}0.010^{*} \\
(0.006)\end{array}$ \\
\hline Male $\times$ Dad Immig & & & $\begin{array}{l}0.003^{*} \\
(0.002)\end{array}$ & $\begin{array}{l}0.004^{*} \\
(0.002)\end{array}$ & $\begin{array}{c}0.002 \\
(0.003)\end{array}$ & & & $\begin{array}{c}0.004 \\
(0.003)\end{array}$ & $\begin{array}{l}-0.004 \\
(0.004)\end{array}$ & $\begin{array}{c}0.000 \\
(0.006)\end{array}$ \\
\hline Male $\times$ Married & & $\begin{array}{c}-0.002^{* * *} \\
(0.001)\end{array}$ & $\begin{array}{c}-0.002^{* * *} \\
(0.001)\end{array}$ & $\begin{array}{l}-0.000 \\
(0.001)\end{array}$ & $\begin{array}{l}-0.000 \\
(0.001)\end{array}$ & & $\begin{array}{c}-0.003^{* * *} \\
(0.001)\end{array}$ & $\begin{array}{c}-0.003^{* *} \\
(0.001)\end{array}$ & $\begin{array}{l}-0.000 \\
(0.002)\end{array}$ & $\begin{array}{l}-0.000 \\
(0.003)\end{array}$ \\
\hline $\mathrm{N}$ & 585,381 & 585,381 & 585,381 & 340,562 & 340,562 & 274,267 & 274,267 & 274,267 & 88,653 & 88,653 \\
\hline Mean of Y & 0.016 & 0.016 & 0.016 & 0.014 & 0.014 & 0.018 & 0.018 & 0.018 & 0.015 & 0.015 \\
\hline $\begin{array}{l}\text { Total Population OLS } \\
\text { Sibling Sample OLS } \\
\text { Sibling Sample FE }\end{array}$ & $\mathrm{X}$ & $\mathrm{X}$ & $\mathrm{X}$ & $\mathrm{X}$ & $\mathrm{X}$ & $\mathrm{X}$ & $\mathrm{X}$ & $\mathrm{X}$ & $\mathrm{X}$ & $\mathrm{X}$ \\
\hline
\end{tabular}

Standard errors in parentheses, clustered at the family level. ${ }^{*} p<0.1,{ }^{* *} p<0.05,{ }^{* * *} p<0.01$. The samples consist of individuals born from 1986-1995. Behevioral \& Emotional Disorder indicates whether the person has been diagnosed with ICD-10 codes F90-98 by the age of 21 years at a hospital. Special education indicates whether the person attends special education during grade 9 and is only observed for years $2007-2011$. All models control for year of birth dummies, month of birth dummies, birth order dummies, maternal age at birth (linear, squared, and cubed), and a constant. All OLS models additionally control for family size dummies and those variables of family environment that are interacted with the male dummy, and the FE models control for family fixed effects. 
Table 5 shows the male-cohort-family environment interactions in a regression with grade 9 completion on time. The base male-female gap in grade 9 on time has increased modestly over time [Column (1)]; boys in the omitted group born from 1973 to 1978 were 8.6 percentage points less likely to complete grade 9 on time compared to girls, and this gap increased to more than 11 percentage points for those born between 1990 and 1995. In contrast, the male premium in the effects of maternal and paternal education has been relatively stable over this time period [Columns (2) to (5)]. This indicates that the gender gap in the effects of parental education is not a recent phenomenon, but has been relatively constant over more than two decades. This suggests in turn that the effects on adult outcomes that we will observe for older cohorts may be predictive of the experiences of more recent cohorts. Meanwhile, the male advantage of being born to married parents has declined and is not significant for the youngest cohort [Column (8)], which may indicate that the role of cohabitation has changed over time.

The impacts of immigrant parents have also changed over cohorts as the composition of the immigrant population has changed.

Table 5

Grade 9 On Time by Birth Cohort: Male-Cohort-Family Environment Interactions

\begin{tabular}{|c|c|c|c|c|c|c|c|c|}
\hline & $\begin{array}{l}\text { Male } \\
(1)\end{array}$ & $\begin{array}{c}\text { Mom HS } \\
(2)\end{array}$ & $\begin{array}{c}\text { Mom } \\
\text { BA } \\
(3)\end{array}$ & $\begin{array}{c}\text { Dad HS } \\
(4)\end{array}$ & $\begin{array}{c}\text { Dad BA } \\
(5)\end{array}$ & $\begin{array}{c}\text { Mom Im } \\
(6)\end{array}$ & $\begin{array}{c}\text { Dad Im } \\
\quad(7)\end{array}$ & $\begin{array}{c}\text { Married } \\
(8)\end{array}$ \\
\hline Male $\times 1973-78$ & $\begin{array}{c}-0.086^{* * *} \\
(0.007)\end{array}$ & $\begin{array}{c}0.016^{* * *} \\
(0.004)\end{array}$ & $\begin{array}{c}0.022^{* * *} \\
(0.005)\end{array}$ & $\begin{array}{c}0.009^{* *} \\
(0.004)\end{array}$ & $\begin{array}{c}0.016^{* * * *} \\
(0.005)\end{array}$ & $\begin{array}{c}0.028^{* * * *} \\
(0.010)\end{array}$ & $\begin{array}{c}0.028^{* * *} \\
(0.010)\end{array}$ & $\begin{array}{c}0.017^{* * *} \\
(0.006)\end{array}$ \\
\hline Male $\times 1979-84$ & $\begin{array}{c}-0.094^{* * *} \\
(0.005)\end{array}$ & $\begin{array}{c}0.009^{* *} \\
(0.004)\end{array}$ & $\begin{array}{c}0.016^{* * *} \\
(0.004)\end{array}$ & $\begin{array}{c}0.006 \\
(0.004)\end{array}$ & $\begin{array}{c}0.022^{* * *} \\
(0.005)\end{array}$ & $\begin{array}{c}0.019^{* *} \\
(0.009)\end{array}$ & $\begin{array}{c}0.019^{* *} \\
(0.009)\end{array}$ & $\begin{array}{c}0.019^{* * *} \\
(0.005)\end{array}$ \\
\hline Male×1985-89 & $\begin{array}{c}-0.110^{* * *} \\
(0.006)\end{array}$ & $\begin{array}{c}0.014^{* * *} \\
(0.005)\end{array}$ & $\begin{array}{c}0.022^{* * * *} \\
(0.005)\end{array}$ & $\begin{array}{c}0.008 \\
(0.005)\end{array}$ & $\begin{array}{c}0.019^{* * *} \\
(0.006)\end{array}$ & $\begin{array}{c}0.012 \\
(0.010)\end{array}$ & $\begin{array}{c}0.006 \\
(0.010)\end{array}$ & $\begin{array}{c}0.010^{* *} \\
(0.004)\end{array}$ \\
\hline Male $\times 1990-95$ & $\begin{array}{c}-0.113^{* * *} \\
(0.006)\end{array}$ & $\begin{array}{c}0.010^{* *} \\
(0.005)\end{array}$ & $\begin{array}{c}0.015^{* * *} \\
(0.005)\end{array}$ & $\begin{array}{l}0.009^{*} \\
(0.005)\end{array}$ & $\begin{array}{c}0.019^{* * *} \\
(0.006)\end{array}$ & $\begin{array}{c}0.028^{* * * *} \\
(0.010)\end{array}$ & $\begin{array}{c}-0.020^{* *} \\
(0.009)\end{array}$ & $\begin{array}{c}0.006 \\
(0.004)\end{array}$ \\
\hline
\end{tabular}

Standard errors in parentheses, clustered at the family level. ${ }^{*} p<0.1,{ }^{* *} p<0.05,{ }^{* * *} p<0.01$. The sample used for estimation is the sibling with individuals born from 1973-1995. $N=898,933$. The outcome is Grade 9 on time with a mean of 0.858 . All estimates come from one regression as specified in equation (3), i.e. a regression interacting the male-family environment interactions as well as the family environment variables with birth cohort dummies. The model controls additionally for family fixed effects, year of birth dummies, month of birth dummies, birth order dummies, maternal age at birth (linear, squared, and cubed), and a constant.

In general, our results on school and behavioral outcomes in adolescence are con- 
sistent with previous studies finding that boys benefit more from a good family background than girls in terms of outcomes indicative of learning and developmental problems (Bedard and Witman, 2015; Bertrand and Pan, 2013; Autor et al., 2016). Using Danish data, we are able to support the overall finding for the U.S. that boys seem more vulnerable to a disadvantageous family environment than their sisters when looking at adolescent outcomes. Notably, we find that boys benefit differentially from high paternal education, and that the effects of parental education have been relatively stable over time.

\subsection{Adult Outcomes}

When we turn to educational attainment, employment, and earnings at age 27 we find, in contrast to school-age outcomes, that women benefit more from higher maternal education than men. This is true for both samples and is robust to the inclusion of family fixed effects. For the total population, men complete less education than women with a raw gender gap of 4.0 months [Table 6, Column (1)]. This gap is strongly increasing in maternal education [Column (2)]. The gender gap in educational attainment rises from 3.3 months for children of less than HS mothers to 4.6 and 6.1 months in families with, respectively, HS and BA educated mothers [Column (3)]; these results are insensitive to the inclusion of family fixed effects [Column (4)]. Paternal education, on the other hand, seems to benefit sons more than daughters, though the effects are smaller than those of maternal education, especially for the total population. Having a HS or BA educated father reduces the gender gap by only about 0.6 months [Column (5)]. ${ }^{25}$ Neither marital status at birth nor childhood family structure significantly affect the gender gap in educational attainment, while having an immigrant father differentially benefits daughters. ${ }^{26}$ Consequently, these results do not support the hypothesis that men are more vulnerable to a disadvantageous family background than women.

\footnotetext{
${ }^{25}$ In results not reported here, we have also considered the natural logarithm of educational attainment to examine whether we would find a similar pattern when looking at relative instead of absolute differences. Those results are in line with the ones reported here on educational attainment.

${ }^{26}$ In results not reported here, we find that this effect is limited to non-Western immigrant fathers.
} 
Table 6

Educational Attainment at Age 27

\begin{tabular}{|c|c|c|c|c|c|c|c|c|c|c|}
\hline & \multicolumn{5}{|c|}{ Highest Completed Education (Months) } & \multicolumn{5}{|c|}{ BA Degree } \\
\hline & (1) & $(2)$ & (3) & $(4)$ & $(5)$ & $(6)$ & $(7)$ & $(8)$ & $(9)$ & $(10)$ \\
\hline Male & $\begin{array}{c}-4.000^{* * *} \\
(0.063)\end{array}$ & $\begin{array}{c}-3.166^{* * *} \\
(0.158)\end{array}$ & $\begin{array}{c}-3.293^{* * *} \\
(0.282)\end{array}$ & $\begin{array}{c}-3.435^{* * *} \\
(0.341)\end{array}$ & $\begin{array}{c}-3.011^{* * *} \\
(0.334)\end{array}$ & $\begin{array}{c}-0.137^{* * * *} \\
(0.001)\end{array}$ & $\begin{array}{c}-0.094^{* * *} \\
(0.002)\end{array}$ & $\begin{array}{c}-0.091^{* * *} \\
(0.004)\end{array}$ & $\begin{array}{c}-0.095 * * * \\
(0.005)\end{array}$ & $\begin{array}{c}-0.079 * * * \\
(0.005)\end{array}$ \\
\hline Male $\times$ Mom HS & & $\begin{array}{c}-1.317^{* * *} \\
(0.143)\end{array}$ & $\begin{array}{c}-1.345^{* * *} \\
(0.191)\end{array}$ & $\begin{array}{c}-1.233^{* * *} \\
(0.230)\end{array}$ & $\begin{array}{c}-1.217^{* * *} \\
(0.230)\end{array}$ & & $\begin{array}{c}-0.035^{* * *} \\
(0.002)\end{array}$ & $\begin{array}{c}-0.035^{* * *} \\
(0.003)\end{array}$ & $\begin{array}{c}-0.031^{* * *} \\
(0.004)\end{array}$ & $\begin{array}{c}-0.030^{* * *} \\
(0.004)\end{array}$ \\
\hline Male $\times$ Mom BA & & $\begin{array}{c}-2.711^{* * *} \\
(0.180)\end{array}$ & $\begin{array}{c}-2.831^{* * *} \\
(0.235)\end{array}$ & $\begin{array}{c}-2.861^{* * *} \\
(0.285)\end{array}$ & $\begin{array}{c}-2.861^{* * *} \\
(0.285)\end{array}$ & & $\begin{array}{c}-0.065^{* * *} \\
(0.003)\end{array}$ & $\begin{array}{c}-0.067^{* * *} \\
(0.004)\end{array}$ & $\begin{array}{c}-0.066^{* * *} \\
(0.005)\end{array}$ & $\begin{array}{c}-0.065^{* * *} \\
(0.005)\end{array}$ \\
\hline Male $\times$ Dad HS & & $\begin{array}{c}0.106 \\
(0.146)\end{array}$ & $\begin{array}{c}0.389 * * \\
(0.196)\end{array}$ & $\begin{array}{c}0.582^{* *} \\
(0.232)\end{array}$ & $\begin{array}{c}0.597^{* *} \\
(0.232)\end{array}$ & & $\begin{array}{c}-0.022^{* * *} \\
(0.002)\end{array}$ & $\begin{array}{c}-0.019^{* * *} \\
(0.003)\end{array}$ & $\begin{array}{c}-0.019 * * * \\
(0.004)\end{array}$ & $\begin{array}{c}-0.017^{* * *} \\
(0.004)\end{array}$ \\
\hline Male $\times$ Dad BA & & $\begin{array}{c}0.433^{* *} \\
(0.206)\end{array}$ & $\begin{array}{c}0.564^{* *} \\
(0.272)\end{array}$ & $\begin{array}{c}0.649^{* *} \\
(0.328)\end{array}$ & $\begin{array}{c}0.661^{* *} \\
(0.328)\end{array}$ & & $\begin{array}{c}0.014^{* * *} \\
(0.004)\end{array}$ & $\begin{array}{c}0.016^{* * *} \\
(0.005)\end{array}$ & $\begin{array}{c}0.017^{* * *} \\
(0.006)\end{array}$ & $\begin{array}{c}0.019 * * * \\
(0.006)\end{array}$ \\
\hline Male $\times$ Mom Immig & & $\begin{array}{c}-0.974^{* *} \\
(0.394)\end{array}$ & $\begin{array}{l}-0.610 \\
(0.515)\end{array}$ & $\begin{array}{l}-0.248 \\
(0.615)\end{array}$ & $\begin{array}{l}-0.236 \\
(0.615)\end{array}$ & & $\begin{array}{c}0.029^{* * *} \\
(0.006)\end{array}$ & $\begin{array}{c}0.046^{* * *} \\
(0.008)\end{array}$ & $\begin{array}{c}0.051^{* * *} \\
(0.010)\end{array}$ & $\begin{array}{c}0.052^{* * *} \\
(0.010)\end{array}$ \\
\hline Male $\times$ Dad Immig & & $\begin{array}{c}-1.940^{* * *} \\
(0.383)\end{array}$ & $\begin{array}{c}-2.728^{* * *} \\
(0.513)\end{array}$ & $\begin{array}{c}-1.658^{* * *} \\
(0.608)\end{array}$ & $\begin{array}{c}-1.665^{* * *} \\
(0.608)\end{array}$ & & $\begin{array}{c}0.023^{* * *} \\
(0.006)\end{array}$ & $\begin{array}{c}0.012 \\
(0.008)\end{array}$ & $\begin{array}{c}0.016 \\
(0.010)\end{array}$ & $\begin{array}{c}0.015 \\
(0.010)\end{array}$ \\
\hline Male $\times$ Married & & $\begin{array}{c}0.340^{* *} \\
(0.140)\end{array}$ & $\begin{array}{c}0.195 \\
(0.262)\end{array}$ & $\begin{array}{c}0.226 \\
(0.322)\end{array}$ & & & $\begin{array}{c}-0.011^{* * *} \\
(0.002)\end{array}$ & $\begin{array}{c}-0.022^{* * *} \\
(0.004)\end{array}$ & $\begin{array}{c}-0.019 * * * \\
(0.005)\end{array}$ & \\
\hline Male×Trad 12 & & & & & $\begin{array}{c}-0.263 \\
(0.312)\end{array}$ & & & & & $\begin{array}{c}-0.044^{* * *} \\
(0.005)\end{array}$ \\
\hline Male $\times$ Step 12 & & & & & $\begin{array}{l}-0.408 \\
(0.462)\end{array}$ & & & & & $\begin{array}{c}0.001 \\
(0.007)\end{array}$ \\
\hline $\mathrm{N}$ & 637,130 & 637,130 & 359,747 & 359,747 & 359,747 & 637,130 & 637,130 & 359,747 & 359,747 & 359,747 \\
\hline Mean of $Y$ & 156.162 & 156.162 & 157.218 & 157.218 & 157.218 & 0.261 & 0.261 & 0.275 & 0.275 & 0.275 \\
\hline Total Population OLS & $\mathrm{X}$ & $\mathrm{X}$ & & & & $\mathrm{X}$ & $\mathrm{X}$ & & & \\
\hline Sibling Sample OLS & & & $\mathrm{X}$ & & & & & $\mathrm{X}$ & & \\
\hline Sibling Sample FE & & & & $\mathrm{X}$ & $\mathrm{X}$ & & & & $\mathrm{X}$ & $\mathrm{X}$ \\
\hline
\end{tabular}

Standard errors in parentheses, clustered at the family level. ${ }^{*} p<0.1,{ }^{* *} p<0.05,{ }^{* * *} p<0.01$. The samples consist of individuals born from 1973-1984. Highest completed education measures the length of highest completed education in months. BA graduate indicates whether the person has at least a BA degree. All models control for year of birth dummies, month of birth dummies, birth order dummies, maternal age at birth (linear, squared, and cubed), two dummies for being observed at age 26 or 28 instead of at age 27, and a constant. All OLS models additionally control for family size dummies and those variables of family environment that are interacted with the male dummy, and the FE models control for family fixed effects. 
Table 7

Labor Market Outcomes at Age 27

\begin{tabular}{|c|c|c|c|c|c|c|c|c|c|c|}
\hline & & \multicolumn{2}{|r|}{$\begin{array}{c}\text { Employed } \\
(3)\end{array}$} & $(4)$ & $(5)$ & \multicolumn{5}{|c|}{ Earnings Percentile by Birth Cohort and Gender } \\
\hline Male & $\begin{array}{c}0.032^{* * *} \\
(0.001)\end{array}$ & $\begin{array}{c}0.054^{* * *} \\
(0.002)\end{array}$ & $\begin{array}{c}0.054^{* * *} \\
(0.004)\end{array}$ & $\begin{array}{c}0.061^{* * *} \\
(0.005)\end{array}$ & $\begin{array}{c}0.070^{* * *} \\
(0.005)\end{array}$ & $\begin{array}{c}0.004^{* * *} \\
(0.001)\end{array}$ & $\begin{array}{c}0.026^{* * *} \\
(0.002)\end{array}$ & $\begin{array}{c}0.032^{* * *} \\
(0.004)\end{array}$ & $\begin{array}{c}0.032^{* * *} \\
(0.005)\end{array}$ & $\begin{array}{c}0.037^{* * *} \\
(0.005)\end{array}$ \\
\hline Male $\times$ Mom HS & & $\begin{array}{c}-0.023^{* * *} \\
(0.002)\end{array}$ & $\begin{array}{c}-0.025^{* * *} \\
(0.002)\end{array}$ & $\begin{array}{c}-0.029^{* * *} \\
(0.003)\end{array}$ & $\begin{array}{c}-0.028 * * * \\
(0.003)\end{array}$ & & $\begin{array}{c}-0.015^{* * *} \\
(0.002)\end{array}$ & $\begin{array}{c}-0.016^{* * *} \\
(0.002)\end{array}$ & $\begin{array}{c}-0.019 * * * \\
(0.003)\end{array}$ & $\begin{array}{c}-0.018^{* * *} \\
(0.003)\end{array}$ \\
\hline Male $\times$ Mom BA & & $\begin{array}{c}-0.024^{* * *} \\
(0.002)\end{array}$ & $\begin{array}{c}-0.027^{* * *} \\
(0.003)\end{array}$ & $\begin{array}{c}-0.028^{* * *} \\
(0.004)\end{array}$ & $\begin{array}{c}-0.027^{* * *} \\
(0.004)\end{array}$ & & $\begin{array}{c}-0.016^{* * *} \\
(0.002)\end{array}$ & $\begin{array}{c}-0.020 * * * \\
(0.003)\end{array}$ & $\begin{array}{c}-0.027^{* * *} \\
(0.004)\end{array}$ & $\begin{array}{c}-0.027^{* * *} \\
(0.004)\end{array}$ \\
\hline Male×Dad HS & & $\begin{array}{c}-0.013^{* * *} \\
(0.002)\end{array}$ & $\begin{array}{c}-0.012^{* * *} \\
(0.002)\end{array}$ & $\begin{array}{c}-0.019 * * * \\
(0.003)\end{array}$ & $\begin{array}{c}-0.019 * * * \\
(0.003)\end{array}$ & & $\begin{array}{c}-0.011^{* * *} \\
(0.002)\end{array}$ & $\begin{array}{c}-0.014^{* * *} \\
(0.002)\end{array}$ & $\begin{array}{c}-0.020^{* * *} \\
(0.003)\end{array}$ & $\begin{array}{c}-0.019^{* * *} \\
(0.003)\end{array}$ \\
\hline Male $\times$ Dad BA & & $\begin{array}{c}-0.019 * * * \\
(0.002)\end{array}$ & $\begin{array}{c}-0.019 * * * \\
(0.003)\end{array}$ & $\begin{array}{c}-0.025^{* * *} \\
(0.004)\end{array}$ & $\begin{array}{c}-0.024^{* * * *} \\
(0.004)\end{array}$ & & $\begin{array}{c}-0.034^{* * *} \\
(0.003)\end{array}$ & $\begin{array}{c}-0.040^{* * *} \\
(0.004)\end{array}$ & $\begin{array}{c}-0.047^{* * *} \\
(0.005)\end{array}$ & $\begin{array}{c}-0.047^{* * *} \\
(0.005)\end{array}$ \\
\hline Male $\times$ Mom Immig & & $\begin{array}{l}0.009^{*} \\
(0.005)\end{array}$ & $\begin{array}{c}0.009 \\
(0.007)\end{array}$ & $\begin{array}{c}0.011 \\
(0.009)\end{array}$ & $\begin{array}{c}0.012 \\
(0.009)\end{array}$ & & $\begin{array}{c}-0.011^{* *} \\
(0.005)\end{array}$ & $\begin{array}{c}-0.016^{* *} \\
(0.007)\end{array}$ & $\begin{array}{l}-0.007 \\
(0.009)\end{array}$ & $\begin{array}{c}-0.006 \\
(0.009)\end{array}$ \\
\hline Male×Dad Immig & & $\begin{array}{c}0.002 \\
(0.005)\end{array}$ & $\begin{array}{c}0.005 \\
(0.007)\end{array}$ & $\begin{array}{c}0.024^{* * *} \\
(0.009)\end{array}$ & $\begin{array}{c}0.024^{* * *} \\
(0.009)\end{array}$ & & $\begin{array}{c}-0.015^{* * *} \\
(0.005)\end{array}$ & $\begin{array}{c}-0.013^{* *} \\
(0.007)\end{array}$ & $\begin{array}{l}-0.012 \\
(0.008)\end{array}$ & $\begin{array}{l}-0.012 \\
(0.008)\end{array}$ \\
\hline Male $\times$ Married & & $\begin{array}{c}0.002 \\
(0.002)\end{array}$ & $\begin{array}{c}0.006 \\
(0.003)\end{array}$ & $\begin{array}{c}0.006 \\
(0.005)\end{array}$ & & & $\begin{array}{c}0.001 \\
(0.002)\end{array}$ & $\begin{array}{c}0.003 \\
(0.003)\end{array}$ & $\begin{array}{l}0.007^{*} \\
(0.004)\end{array}$ & \\
\hline Male $\times$ Trad 12 & & & & & $\begin{array}{l}-0.006 \\
(0.004)\end{array}$ & & & & & $\begin{array}{c}0.002 \\
(0.004)\end{array}$ \\
\hline Male $\times$ Step 12 & & & & & $\begin{array}{c}0.004 \\
(0.007)\end{array}$ & & & & & $\begin{array}{c}0.007 \\
(0.006)\end{array}$ \\
\hline $\mathrm{N}$ & 639,212 & 639,212 & 361,712 & 361,712 & 361,712 & 563,124 & 563,124 & 292,440 & 292,440 & 292,440 \\
\hline Mean of Y & 0.900 & 0.900 & 0.904 & 0.904 & 0.904 & 0.513 & 0.513 & 0.518 & 0.518 & 0.518 \\
\hline Total Population OLS & $\mathrm{X}$ & $\mathrm{X}$ & & & & $\mathrm{X}$ & $\mathrm{X}$ & & & \\
\hline $\begin{array}{l}\text { Sibling Sample OLS } \\
\text { Sibling Sample FE }\end{array}$ & & & $\mathrm{X}$ & $\mathrm{X}$ & $\mathrm{X}$ & & & $\mathrm{X}$ & $\mathrm{X}$ & $\mathrm{X}$ \\
\hline
\end{tabular}

Standard errors in parentheses, clustered at the family level. ${ }^{*} p<0.1,{ }^{* *} p<0.05,{ }^{* * *} p<0.01$. The samples consist of individuals born from 1973-1984. Employed takes the value one if the person has positive labor earnings or have employment as the main source of income including self-employment and zero otherwise. Earnings percentile measures the annual earnings percentile by gender and year of birth for those with positive labor earnings. All models control for year of birth dummies, month of birth dummies, birth order dummies, maternal age at birth (linear, squared, and cubed), two dummies for being observed at age 26 or 28 instead of at age 27 , and a constant. All OLS models additionally control for family size dummies and those variables of family environment that are interacted with the male dummy, and the FE models control for family fixed effects. 
Turning to the binary outcome of having received a BA degree by age 27 , we find results quite similar to those in the educational attainment model, with two exceptions. First, women of HS educated fathers benefit more than their brothers, though boys benefit more from a college-educated father. Second, women also benefit more than their brothers from having parents who were married when they were born [Columns (7) to (9)] and living in a traditional family during childhood [Column (10)]. These results are sharply at odds with those we saw for school outcomes at age 16: on most dimensions, women benefit more from a favorable childhood family environment than their brothers in terms of higher educational attainment in adulthood.

Table 7 presents results for labor market outcomes at age 27. Column 1 shows that men are 3.2 percentage points more likely to be employed than women. However, we again see the pattern that women benefit more than their brothers from having parents with at least HS education, with effects of maternal and paternal education that are significant and of similar magnitudes. The employment gap is larger for families with an immigrant father when comparing sisters and brothers in fixed effects models [Columns (4) and (5)], which may be a reflection of more traditional gender norms. ${ }^{27}$

For individuals with positive labor earnings, parental education differentially increases the earnings percentile of women relative to their brothers. Women whose parents have at least a HS degree earn more than their brothers relative to their birth cohort and gender, and the effect of paternal college education is particularly strong (4.7 percentage points). We find no gender gap in the effects of childhood family structure on either employment or earnings except for a small borderline significant effect on earnings (favoring boys) of married parents at birth.

\subsection{Adult Outcomes Across Cohorts}

We have found that women consistently benefit more from high maternal education than their brothers in terms of educational attainment and labor market outcomes at age 27. In this section, we examine whether these gender differences in the effects of

\footnotetext{
${ }^{27}$ The immigrant effect is limited to families in which one or both parents is of non-Western origin.
} 
parental education have changed across cohorts.

Figure 3

Highest Completed Education (in Months) at Age 27 by Birth Cohort

Male-Mother's and Male-Father's Education Interaction

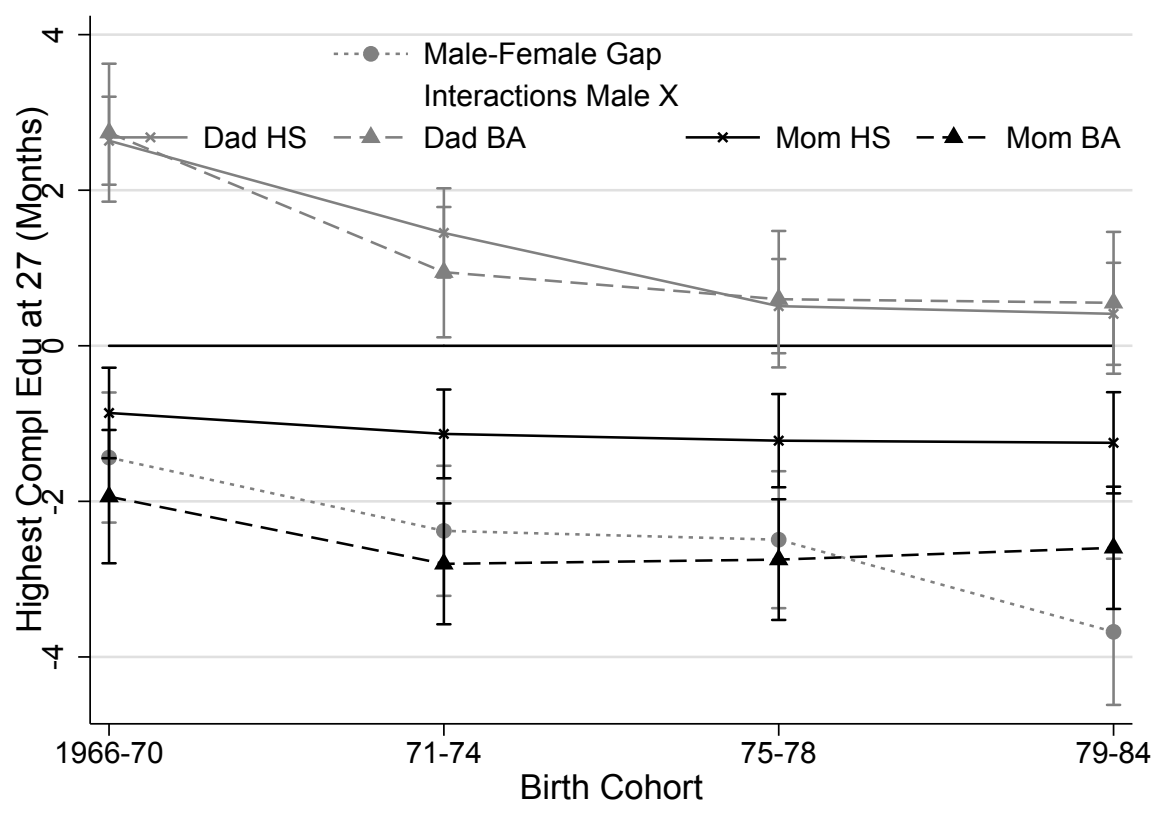

Note: The whiskers represent the 95 percent confidence interval. The sample is the sibling sample with individuals born from 1966-1984. All estimates come from one regression interacting the male-family environment interactions as well as the family environment variables with birth cohort dummies. Appendix Table A3 displays all the male-cohort-family environment interaction estimates. The model additionally controls for family fixed effects, year of birth dummies, month of birth dummies, birth order dummies, maternal age at birth (linear, squared, and cubed), two dummies for being observed at age 26 or 28 instead of at age 27, and a constant.

Figure 3 plots the estimates from an educational attainment regression that now includes interactions between the male dummy, family environment, and cohort dummies. From this, we get two important insights. First, it is evident that earlier cohorts of men benefited more from high paternal education than women but that the gender difference in the effect of father's education has diminished substantially and is no longer significant for recent cohorts. Results reported in the Appendix show a similar pattern of results for receiving a BA degree and also show that the impacts of family structure have been reasonably consistent over time. ${ }^{28}$ Family structure has never sig-

\footnotetext{
${ }^{28}$ Panel A in Appendix Table A3 shows the male-cohort interactions with parental immigrant status and
} 
nificantly affected the gender gap in educational attainment, though living in a stable family during childhood has consistently favored women for all cohorts in terms of the likelihood of receiving a BA. Consequently, this evidence does not support the hypothesis that the increasing prevalence of non-traditional family arrangements explain the growing education gap in favor of girls.

Finally, Table 8 examines whether the gender gap in the effects of childhood family environment on labor market outcomes has changed across cohorts (1973-1978 vs 19661971) and how they vary across ages (27, 33, and 40). The raw employment gap between men and women narrows as they age such that men in the older cohort are only 1.9 percentage points more likely to be employed than women at age 40, compared to a gap of 5.0 percentage points at age 27 [Columns (3) and (5), Panel A]. The gender differences in the effects of parental education on employment at the same age are similar across cohorts though, as siblings age, the differential impact of parental education on men and women in employment falls and has essentially disappeared by age 40 .

The age pattern of parental education effects on the earnings percentile is different. At age 27, both maternal and paternal education have more positive effects on women's earnings. By age 40, maternal education no longer has a differential effect on sons and daughters, and paternal education has a stronger impact on sons. This change may reflect the different career lifecycles of men and women, especially related to childbirth (Kleven et al. (2015)).

childhood family structure from this model. The impacts of immigrant parents have changed across cohorts, perhaps as a consequence of changing composition of this group. The results in Figure 3 are basically identical when only considering traditional families. Though we do not report the results here, if we exclude the male-paternal education interactions, the gender gap in the effects of maternal education appear to be increasing over time, indicating a spurious trend in the impact of mother's education. 
Table 8

Labor Market Outcomes Across Cohorts and Ages

\begin{tabular}{|c|c|c|c|c|c|c|c|c|c|c|}
\hline \multirow{3}{*}{$\begin{array}{l}\text { Cohort } \\
\text { Age }\end{array}$} & \multicolumn{5}{|c|}{ Employed } & \multicolumn{5}{|c|}{ Earnings Percentile by Birth Cohort and Gender } \\
\hline & \multicolumn{2}{|c|}{$1973-1978$} & \multicolumn{3}{|c|}{$1966-1971$} & \multicolumn{2}{|c|}{$1973-1978$} & \multicolumn{3}{|c|}{$1966-1971$} \\
\hline & $\begin{array}{l}27 \\
(1)\end{array}$ & $\begin{array}{l}33 \\
(2)\end{array}$ & $\begin{array}{l}27 \\
(3)\end{array}$ & $\begin{array}{l}33 \\
(4)\end{array}$ & $\begin{array}{l}40 \\
(5)\end{array}$ & $\begin{array}{l}27 \\
(6)\end{array}$ & $\begin{array}{l}33 \\
(7)\end{array}$ & $\begin{array}{l}27 \\
(8)\end{array}$ & $\begin{array}{l}33 \\
(9)\end{array}$ & $\begin{array}{c}40 \\
(10)\end{array}$ \\
\hline $\begin{array}{l}\text { Panel A } \\
\text { Male }\end{array}$ & $\begin{array}{c}0.042^{* * *} \\
(0.002)\end{array}$ & $\begin{array}{c}0.027^{* * *} \\
(0.002)\end{array}$ & $\begin{array}{c}0.050^{* * *} \\
(0.002)\end{array}$ & $\begin{array}{c}0.042^{* * *} \\
(0.002)\end{array}$ & $\begin{array}{c}0.019^{* * *} \\
(0.002)\end{array}$ & $\begin{array}{c}0.003 \\
(0.003)\end{array}$ & $\begin{array}{c}0.011^{* * * *} \\
(0.002)\end{array}$ & $\begin{array}{c}0.012^{* * *} \\
(0.003)\end{array}$ & $\begin{array}{c}0.010^{* * *} \\
(0.002)\end{array}$ & $\begin{array}{c}0.002 \\
(0.002)\end{array}$ \\
\hline $\begin{array}{l}\text { Panel B } \\
\text { Male }\end{array}$ & $\begin{array}{c}0.080^{* * *} \\
(0.009)\end{array}$ & $\begin{array}{c}0.042^{* * *} \\
(0.008)\end{array}$ & $\begin{array}{c}0.082^{* * *} \\
(0.007)\end{array}$ & $\begin{array}{c}0.060^{* * *} \\
(0.007)\end{array}$ & $\begin{array}{c}0.021^{* * *} \\
(0.008)\end{array}$ & $\begin{array}{c}0.030^{* * *} \\
(0.009)\end{array}$ & $\begin{array}{c}-0.017^{*} \\
(0.009)\end{array}$ & $\begin{array}{c}0.044^{* * *} \\
(0.009)\end{array}$ & $\begin{array}{l}-0.007 \\
(0.009)\end{array}$ & $\begin{array}{c}-0.032^{* * *} \\
(0.009)\end{array}$ \\
\hline Male×Mom HS & $\begin{array}{c}-0.033^{* * *} \\
(0.005)\end{array}$ & $\begin{array}{c}-0.012^{* *} \\
(0.005)\end{array}$ & $\begin{array}{c}-0.027^{* * *} \\
(0.004)\end{array}$ & $\begin{array}{c}-0.017^{* * *} \\
(0.004)\end{array}$ & $\begin{array}{l}-0.007 \\
(0.004)\end{array}$ & $\begin{array}{c}-0.018^{* * *} \\
(0.006)\end{array}$ & $\begin{array}{c}0.001 \\
(0.006)\end{array}$ & $\begin{array}{c}-0.038^{* * *} \\
(0.006)\end{array}$ & $\begin{array}{c}-0.002 \\
(0.006)\end{array}$ & $\begin{array}{c}0.005 \\
(0.006)\end{array}$ \\
\hline Male $\times$ Mom BA & $\begin{array}{c}-0.030 * * * \\
(0.007)\end{array}$ & $\begin{array}{c}-0.014^{* *} \\
(0.006)\end{array}$ & $\begin{array}{c}-0.023^{* * *} \\
(0.006)\end{array}$ & $\begin{array}{c}-0.015^{* *} \\
(0.006)\end{array}$ & $\begin{array}{c}-0.004 \\
(0.006)\end{array}$ & $\begin{array}{c}-0.037 * * * \\
(0.008)\end{array}$ & $\begin{array}{c}-0.026^{* * *} \\
(0.007)\end{array}$ & $\begin{array}{c}-0.047^{* * *} \\
(0.009)\end{array}$ & $\begin{array}{l}-0.010 \\
(0.008)\end{array}$ & $\begin{array}{l}-0.008 \\
(0.008)\end{array}$ \\
\hline Male×Dad HS & $\begin{array}{c}-0.015^{* * *} \\
(0.005)\end{array}$ & $\begin{array}{c}-0.019^{* * *} \\
(0.005)\end{array}$ & $\begin{array}{c}-0.010^{* *} \\
(0.004)\end{array}$ & $\begin{array}{c}-0.009^{* *} \\
(0.004)\end{array}$ & $\begin{array}{c}-0.008^{*} \\
(0.004)\end{array}$ & $\begin{array}{c}-0.015^{* *} \\
(0.006)\end{array}$ & $\begin{array}{c}0.022^{* * *} \\
(0.006)\end{array}$ & $\begin{array}{l}-0.007 \\
(0.006)\end{array}$ & $\begin{array}{c}0.012^{* *} \\
(0.005)\end{array}$ & $\begin{array}{c}0.020^{* * *} \\
(0.005)\end{array}$ \\
\hline Male×Dad BA & $\begin{array}{c}-0.019^{* *} \\
(0.007)\end{array}$ & $\begin{array}{c}-0.015^{* *} \\
(0.007)\end{array}$ & $\begin{array}{c}-0.017^{* *} \\
(0.007)\end{array}$ & $\begin{array}{c}-0.018^{* * *} \\
(0.006)\end{array}$ & $\begin{array}{l}-0.008 \\
(0.006)\end{array}$ & $\begin{array}{c}-0.052^{* * *} \\
(0.009)\end{array}$ & $\begin{array}{c}0.013 \\
(0.008)\end{array}$ & $\begin{array}{c}-0.033^{* * *} \\
(0.009)\end{array}$ & $\begin{array}{c}0.010 \\
(0.009)\end{array}$ & $\begin{array}{c}0.026^{* * *} \\
(0.008)\end{array}$ \\
\hline Male $\times$ Mom Immig & $\begin{array}{c}0.058^{* * *} \\
(0.016)\end{array}$ & $\begin{array}{c}0.022 \\
(0.015)\end{array}$ & $\begin{array}{c}0.031^{* *} \\
(0.013)\end{array}$ & $\begin{array}{c}0.022^{*} \\
(0.013)\end{array}$ & $\begin{array}{l}-0.004 \\
(0.014)\end{array}$ & $\begin{array}{l}-0.002 \\
(0.016)\end{array}$ & $\begin{array}{l}-0.025 \\
(0.017)\end{array}$ & $\begin{array}{c}0.011 \\
(0.019)\end{array}$ & $\begin{array}{l}-0.014 \\
(0.018)\end{array}$ & $\begin{array}{c}0.008 \\
(0.018)\end{array}$ \\
\hline Male $\times$ Dad Immig & $\begin{array}{c}0.012 \\
(0.016)\end{array}$ & $\begin{array}{c}0.001 \\
(0.014)\end{array}$ & $\begin{array}{c}0.005 \\
(0.015)\end{array}$ & $\begin{array}{c}0.012 \\
(0.015)\end{array}$ & $\begin{array}{l}-0.009 \\
(0.015)\end{array}$ & $\begin{array}{c}-0.014 \\
(0.017)\end{array}$ & $\begin{array}{l}-0.009 \\
(0.017)\end{array}$ & $\begin{array}{c}0.014 \\
(0.021)\end{array}$ & $\begin{array}{c}0.013 \\
(0.019)\end{array}$ & $\begin{array}{l}-0.031 \\
(0.019)\end{array}$ \\
\hline Male×Trad 12 & $\begin{array}{c}-0.014^{*} \\
(0.008)\end{array}$ & $\begin{array}{c}0.003 \\
(0.007)\end{array}$ & $\begin{array}{c}-0.018^{* *} \\
(0.007)\end{array}$ & $\begin{array}{l}-0.006 \\
(0.007)\end{array}$ & $\begin{array}{c}0.007 \\
(0.007)\end{array}$ & $\begin{array}{c}0.009 \\
(0.008)\end{array}$ & $\begin{array}{c}0.026^{* * *} \\
(0.008)\end{array}$ & $\begin{array}{l}-0.007 \\
(0.009)\end{array}$ & $\begin{array}{l}0.014^{*} \\
(0.009)\end{array}$ & $\begin{array}{c}0.023^{* * *} \\
(0.008)\end{array}$ \\
\hline Male $\times$ Step 12 & $\begin{array}{c}0.005 \\
(0.011)\end{array}$ & $\begin{array}{c}0.016 \\
(0.011)\end{array}$ & $\begin{array}{c}0.002 \\
(0.011)\end{array}$ & $\begin{array}{l}-0.009 \\
(0.011)\end{array}$ & $\begin{array}{c}0.004 \\
(0.012)\end{array}$ & $\begin{array}{c}0.014 \\
(0.013)\end{array}$ & $\begin{array}{c}0.007 \\
(0.012)\end{array}$ & $\begin{array}{c}0.016 \\
(0.014)\end{array}$ & $\begin{array}{l}-0.001 \\
(0.014)\end{array}$ & $\begin{array}{c}0.010 \\
(0.013)\end{array}$ \\
\hline $\mathrm{N}$ & 125,930 & 125,930 & 151,727 & 151,727 & 151,727 & 85,981 & 85,981 & 87,982 & 87,982 & 87,982 \\
\hline Mean of Y & 0.903 & 0.917 & 0.924 & 0.925 & 0.917 & 0.526 & 0.535 & 0.538 & 0.545 & 0.539 \\
\hline
\end{tabular}

Standard errors in parentheses, clustered at the family level. ${ }^{*} p<0.1,{ }^{* *} p<0.05,{ }^{* * *} p<0.01$. The samples are subsamples of sibling sample with individuals born from respectively 1963-71 and 1973-79. Estimates in each column in each panel come from separate regressions. Employed takes the value one if the person has positive wage earnings or have employment as the main source of income including self-employment and zero otherwise. Earnings percentile measures the annual earnings percentile by gender and year of birth for those with positive labor earnings. All models control for family fixed effects, year of birth dummies, month of birth dummies, birth order dummies, maternal age at birth (linear, squared, and cubed), two dummies for being observed at age 26 or 28 (32 or 34/39 or 40) instead of at age 27 (33/40), and a constant. 
The results in this section show that gender differences in the effects of parental education have been fairly constant across cohorts in terms of educational attainment, with the exception that the differentially positive effect of father's education on boys has decreased over time. The same is true of labor market outcomes: the gender specific responses to childhood family environment have been consistent across cohorts, though the more positive effects of both maternal and paternal education on women's employment and earnings tends to diminish with age.

\subsection{Sensitivity Analyses}

In this subsection, we study the robustness of our findings in three different ways. First, we examine whether different aspects of childhood family environment interact in important ways by gender. Second, we check the robustness of our measure of childhood family structure. Since the main results were quite similar for the different models, we perform these two robustness analyses on the sibling sample including family fixed effects. Third, we compare our main results (estimated on the total population and the sibling sample) to the estimated effects for one-child families and subsamples of the sibling sample divided by the gender composition of the siblings in the sample without family fixed effects.

Appendix Table A4 includes interactions between mother's and father's education in several key models of school and adult outcomes. ${ }^{29}$ We find some heterogeneity in the effects of parents' education on educational attainment at age 27.30 The results suggest that in families where the mother has at least HS education, men do not benefit differently than their sisters from father's HS education in terms of highest completed education. For college graduation, the excess female advantage from parental BA education is smaller in families where both parents have at least HS education. Appendix Table A5 expands the main model by interacting the family environment-male inter-

\footnotetext{
${ }^{29}$ The correlation between mother's and father's length of education is around 0.40 and approximately 50 percent of parents have the same educational level.

${ }^{30}$ Formally, we test this with an F-test of whether the additional Male $\times$ Mom Edu $\times$ Dad Edu interaction terms are jointly equal to zero.
} 
actions with marital status at birth, but we find little evidence of heterogeneity.

Appendix Table A6 tests the sensitivity of our definition of childhood family structure for the sibling sample, which is based on the experience of the youngest sibling. Column (1) (and every second column) uses family structure defined for the oldest sibling instead; the results are very robust to this change in our measure of childhood family structure. In Column (2) (and every second column), we restrict the sample to those families with children with the same observed family structure at age 12 ; the results are again very similar to the main results.

Finally, Appendix Tables A7 and A8 compare OLS models of key outcomes for alternative samples - the total population, children from one-child families, and the sample of full siblings (which we also split by gender composition for the OLS estimations [Columns (4) and (5)]). Overall, the estimates for the different subsamples and for the total population and the sibling sample without fixed effects are similar (both in terms of magnitude and significance), though fewer estimates are significant in smaller samples.

\section{Conclusion}

Motivated by previous findings showing that school-aged boys appear more vulnerable to family disadvantage than school-aged girls, we examine whether such differences persist into adulthood. We use Danish administrative register data, allowing us to examine a broad range of school and adult outcomes for complete cohorts, as well as large samples of full siblings. An advantage compared to previous studies is that we observe both mother's and father's education as well as family structure at birth and during childhood.

In line with findings from the U.S. (Autor et al., 2016; Lundberg, 2016), we first show that in the Danish context boys also appear to be generally more sensitive than girls to family environment in terms of observable outcomes during school. We find the opposite for adult outcomes, including educational attainment, college graduation, 
employment, and earnings. Women consistently benefit more from maternal education relative to their brothers in terms of education and employment. Paternal education decreases the gender gap in education (favoring sons), though the impact is small. In contrast, paternal education has larger positive effects on the employment and earnings of daughters. A gender gap in the effects of family structure only exists for college graduation and favors women. Similar results in OLS models using the entire population and family fixed-effect models using a sample of full siblings indicate that selection of boys and girls across family types is not a serious source of bias.

Moreover, we show the gender gap in the effects of parental education on completing grade 9 on time has been relatively constant over more than two decades. This indicates that the gender difference in the effects of maternal education on primary school completion is not a recent phenomenon. In terms of educational attainment in adulthood, we find that men used to benefit more from paternal education than women but that the gender difference in the effect of father's education disappeared for cohorts born after the mid-1970s. The female premium in the effects of mother's education has been constant for all cohorts.

Although boys respond differently to parental resources and family structure than do girls, the evidence shows that such gender differences do not conform to the simple story that the skill development of boys is particularly sensitive to family environment. Neither can the changes in family structure, in the Danish context, explain the growing education gap in favor of girls. Our findings are compatible with a story in which parental education and other family resources have a strong moderating effect on behavioral problems in school that are much more typical of boys than girls. These controlling forces may become less effective as the children become adults, and the results show no indication that long-term skill acquisition, and therefore educational attainment or adult earnings, is affected. These results fail to support a particular targeting of boys in programs designed to assist students from disadvantaged families. 


\section{Acknowledgements}

We are thankful for helpful comments and suggestions from Edward Samuel Jones, Torben Heien Nielsen, Hans Henrik Sievertsen, Dick Startz, and Miriam Wüst, as well as seminar participants at University of California, Santa Barbara, at the DAEiNA conference at Aarhus University, and at the Copenhagen Education Network Workshop.

\section{Funding Sources}

This research did not receive any specific grant from funding agencies in the public, commercial, or not-for-profit sectors.

\section{References}

Almond, D. and L. Edlund (2007). Trivers-willard at birth and one year: evidence from us natality data 1983-2001. Proceedings of the Royal Society of London B: Biological Sciences 274(1624), 2491-2496.

Autor, D., D. Figlio, K. Karbownik, J. Roth, and M. Wasserman (2016). Family disadvantage and the gender gap in behavioral and educational outcomes. NBER Working Paper Series.

Autor, D. and M. Wasserman (2013). Wayward sons: The emerging gender gap in labor markets and education. Third Way Report 20013.

Baker, M. and K. Milligan (2013). Boy-girl differences in parental time investments: Evidence from three countries. NBER Working Paper Series.

Becker, G. S., W. H. Hubbard, and K. M. Murphy (2010). Explaining the worldwide boom in higher education of women. Journal of Human Capital 4(3), 203-241.

Bedard, K. and A. Witman (2015). Family structure and the gender gap in adhd. 
Bertrand, M. and J. Pan (2013). The trouble with boys: Social influences and the gender gap in disruptive behavior. American Economic Journal: Applied Economics 5(1), 32-64.

Dahl, G. B. and E. Moretti (2008). The demand for sons. The Review of Economic Studies 75(4), 1085-1120.

Dee, T. S. and H. H. Sievertsen (2015). The gift of time? school starting age and mental health. NBER Working Paper Series.

DiPrete, T. A. and C. Buchmann (2013). The rise of women: The growing gender gap in education and what it means for American schools. Russell Sage Foundation.

DiPrete, T. A. and J. L. Jennings (2012). Social and behavioral skills and the gender gap in early educational achievement. Social Science Research 41(1), 1-15.

Duckworth, A. L. and M. E. Seligman (2006). Self-discipline gives girls the edge: Gender in self-discipline, grades, and achievement test scores. Journal of educational psychology 98(1), 198.

Duncan, G. J. and K. Magnuson (2011). The nature and impact of early achievement skills, attention skills, and behavior problems. Whither opportunity, 47-70.

Fan, X., H. Fang, and S. Markussen (2015). Mothers' employment and children's educational gender gap. NBER Working Paper Series.

Fortin, N. M., P. Oreopoulos, and S. Phipps (2015). Leaving boys behind gender disparities in high academic achievement. Journal of Human Resources 50(3), 549579.

Goldin, C., L. F. Katz, and I. Kuziemko (2006). The homecoming of american college women: The reversal of the college gender gap. NBER Working Paper Series.

Hamoudi, A. and J. Nobles (2014). Do daughters really cause divorce? stress, pregnancy, and family composition. Demography 51(4), 1423-1449. 
Kleven, H. J., C. Landais, and J. E. Søgaard (2015). Parenthood and the gender gap: Evidence from denmark.

Kristoffersen, J. H., C. Obel, and N. Smith (2015). Gender differences in behavioral problems and school outcomes. Journal of Economic Behavior $\&$ Organization 115, $75-93$.

Landers $\varnothing$, R. and J. J. Heckman (2016). The scandinavian fantasy: The sources of intergenerational mobility in denmark and the us. IZA Discussion Paper, forthcoming in the Scandinavian Journal of Economics.

Lundberg, S. (2005). Sons, daughters, and parental behaviour. Oxford Review of Economic Policy 21(3), 340-356.

Lundberg, S. (2016). Father absence and the gender gap in college graduation.

Lundberg, S. and E. Rose (2003). Child gender and the transition to marriage. Demography 40(2), 333-349.

Norberg, K. (2004). Partnership status and the human sex ratio at birth. Proceedings of the Royal Society of London B: Biological Sciences 271(1555), 2403-2410.

Obel, C., J. L. Zhu, J. Olsen, S. Breining, J. Li, T. K. Grønborg, M. Gissler, and M. Rutter (2015). The risk of attention deficit hyperactivity disorder in children exposed to maternal smoking during pregnancy-a reexamination using a sibling design. Journal of Child Psychology and Psychiatry.

OECD (2015). The abc of gender equality in education.

Riphahn, R. T. and C. Schwientek (2015). What drives the reversal of the gender education gap? evidence from germany. Applied Economics 47(53), 5748-5775.

Rossin-Slater, M. and M. Wüst (2014). Child support obligations and family outcomes: Causal evidence from administrative data. SFI The Danish National Centre For Social Research. 
Simonsen, M., H. S. Nielsen, and R. Landersø (2015). School starting age and the crime-age profile. Economic Journal.

Trivers, R. L. and D. E. Willard (1973). Natural selection of parental ability to vary the sex ratio of offspring. Science 179(4068), 90-92.

U.S. Census Bureau (2015). Cps historical time series tables. 


\section{A Appendix}

Figure A1

Highest Completed Education (Years) by age 29 by Gender in Denmark

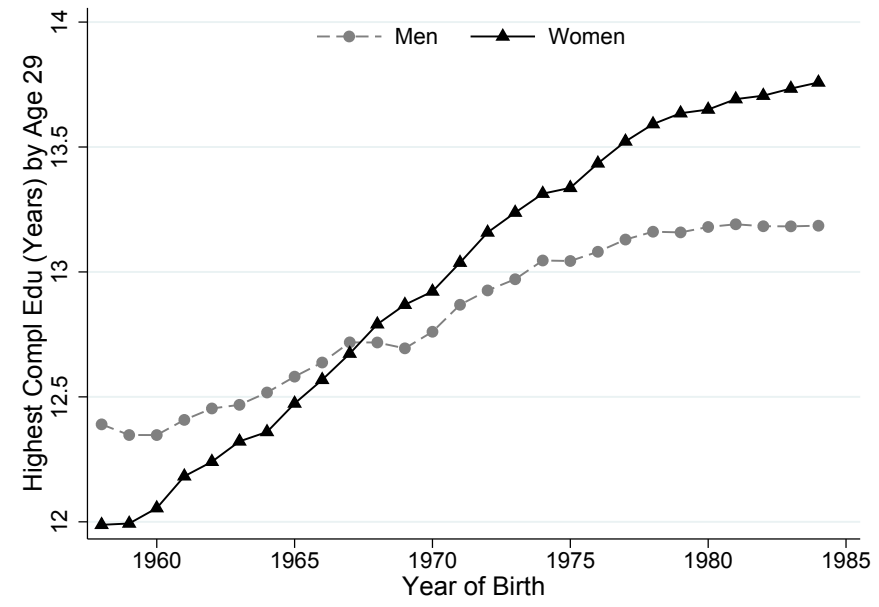

Note: Highest completed education in years by birth cohort (1958-1984) and gender for people living in Denmark.

Table A1

Overview of Samples and Outcomes

\begin{tabular}{lcc}
\hline & Main Analysis & Across Cohorts \\
\hline Outcomes in Adolescence & & \\
Grade 9 On Time & $1986-1995$ & $1973-1995$ \\
Grade 9 GPA & $1986-1995$ & \\
Behavioral \& Emotional Disorder & $1986-1995$ & \\
Special Education & $1991-1995$ & \\
& & \\
Outcomes in Adolthood & $1973-1984$ & $1966-1984$ \\
Education/BA Degree age 27 & $1973-1984$ & $1966-1984$ \\
Employment/Earnings age 27 & & $1973-1978$ \\
Employment/Earnings age 27 \& 33 & & $1966-1971$ \\
Employment/Earnings age 27, 33 \& 40 & & \\
\hline
\end{tabular}

The table summarizes the birth cohorts used for each outcome. See section 3 for more detail. 
Table A2

Prenatal Inputs and Birth Outcomes

\begin{tabular}{|c|c|c|c|c|c|c|c|c|c|c|c|c|}
\hline & \multicolumn{6}{|c|}{ Total Population OLS } & \multicolumn{6}{|c|}{ Sibling Sample FE } \\
\hline & $\begin{array}{c}\text { Check- } \\
\text { ups } \\
\text { (1) }\end{array}$ & $\begin{array}{l}\text { Pregn. } \\
\text { Comp. } \\
\quad(2)\end{array}$ & $\begin{array}{c}\text { Smoke } \\
\text { (3) }\end{array}$ & $\begin{array}{l}\text { Pre- } \\
\text { term } \\
(4)\end{array}$ & $\begin{array}{c}\text { LBW } \\
(5)\end{array}$ & $\begin{array}{l}\text { Low } \\
\text { Apgar } \\
\quad(6)\end{array}$ & $\begin{array}{c}\text { Check- } \\
\text { ups } \\
(7)\end{array}$ & $\begin{array}{c}\text { Pregn. } \\
\text { Comp. } \\
\quad(8)\end{array}$ & $\begin{array}{c}\text { Smoke } \\
\text { (9) }\end{array}$ & $\begin{array}{l}\text { Pre- } \\
\text { term } \\
(10)\end{array}$ & $\begin{array}{l}\text { LBW } \\
(11)\end{array}$ & $\begin{array}{c}\text { Low } \\
\text { Apgar } \\
(12)\end{array}$ \\
\hline \multicolumn{13}{|l|}{ Panel A } \\
\hline Male & $\begin{array}{c}-0.093^{* * *} \\
(0.006)\end{array}$ & $\begin{array}{c}0.001^{* * *} \\
(0.000)\end{array}$ & $\begin{array}{l}-0.000 \\
(0.002)\end{array}$ & $\begin{array}{c}0.008^{* * *} \\
(0.000)\end{array}$ & $\begin{array}{c}-0.004^{* * *} \\
(0.000)\end{array}$ & $\begin{array}{c}0.002^{* * *} \\
(0.000)\end{array}$ & $\begin{array}{c}-0.080^{* * * *} \\
(0.009)\end{array}$ & $\begin{array}{c}0.001 \\
(0.001)\end{array}$ & $\begin{array}{c}0.003 \\
(0.002)\end{array}$ & $\begin{array}{c}0.006^{* * *} \\
(0.001)\end{array}$ & $\begin{array}{c}-0.004^{* * *} \\
(0.001)\end{array}$ & $\begin{array}{c}0.001^{* *} \\
(0.000)\end{array}$ \\
\hline \multicolumn{13}{|l|}{ Panel B } \\
\hline Male & $\begin{array}{c}-0.077^{* * *} \\
(0.016)\end{array}$ & $\begin{array}{l}0.002^{*} \\
(0.001)\end{array}$ & $\begin{array}{l}-0.001 \\
(0.005)\end{array}$ & $\begin{array}{c}0.009^{* * *} \\
(0.001)\end{array}$ & $\begin{array}{c}-0.006^{* * *} \\
(0.001)\end{array}$ & $\begin{array}{c}0.002^{* * *} \\
(0.001)\end{array}$ & $\begin{array}{c}-0.091 * * * \\
(0.027)\end{array}$ & $\begin{array}{c}0.000 \\
(0.002)\end{array}$ & $\begin{array}{l}-0.001 \\
(0.006)\end{array}$ & $\begin{array}{c}0.008 * * * \\
(0.002)\end{array}$ & $\begin{array}{c}-0.005^{* *} \\
(0.002)\end{array}$ & $\begin{array}{c}0.002^{*} \\
(0.001)\end{array}$ \\
\hline Male $\times$ Mom HS & $\begin{array}{l}-0.014 \\
(0.015)\end{array}$ & $\begin{array}{l}-0.000 \\
(0.001)\end{array}$ & $\begin{array}{l}-0.004 \\
(0.004)\end{array}$ & $\begin{array}{c}0.001 \\
(0.001)\end{array}$ & $\begin{array}{c}0.003^{* *} \\
(0.001)\end{array}$ & $\begin{array}{c}0.000 \\
(0.001)\end{array}$ & $\begin{array}{l}-0.020 \\
(0.023)\end{array}$ & $\begin{array}{l}-0.001 \\
(0.002)\end{array}$ & $\begin{array}{c}0.006 \\
(0.006)\end{array}$ & $\begin{array}{c}0.000 \\
(0.002)\end{array}$ & $\begin{array}{c}0.001 \\
(0.002)\end{array}$ & $\begin{array}{c}0.001 \\
(0.001)\end{array}$ \\
\hline Male $\times$ Mom BA & $\begin{array}{c}0.005 \\
(0.017)\end{array}$ & $\begin{array}{l}-0.001 \\
(0.001)\end{array}$ & $\begin{array}{c}0.002 \\
(0.005)\end{array}$ & $\begin{array}{c}-0.003^{* *} \\
(0.001)\end{array}$ & $\begin{array}{c}0.002^{* *} \\
(0.001)\end{array}$ & $\begin{array}{l}-0.000 \\
(0.001)\end{array}$ & $\begin{array}{c}0.023 \\
(0.026)\end{array}$ & $\begin{array}{l}-0.002 \\
(0.002)\end{array}$ & $\begin{array}{c}0.005 \\
(0.007)\end{array}$ & $\begin{array}{c}-0.003^{*} \\
(0.002)\end{array}$ & $\begin{array}{l}-0.000 \\
(0.002)\end{array}$ & $\begin{array}{l}-0.000 \\
(0.001)\end{array}$ \\
\hline Male $\times$ Dad HS & $\begin{array}{l}-0.026^{*} \\
(0.015)\end{array}$ & $\begin{array}{c}0.001 \\
(0.001)\end{array}$ & $\begin{array}{l}-0.001 \\
(0.004)\end{array}$ & $\begin{array}{c}0.000 \\
(0.001)\end{array}$ & $\begin{array}{c}0.001 \\
(0.001)\end{array}$ & $\begin{array}{l}-0.001 \\
(0.001)\end{array}$ & $\begin{array}{c}0.021 \\
(0.023)\end{array}$ & $\begin{array}{c}0.001 \\
(0.002)\end{array}$ & $\begin{array}{l}-0.003 \\
(0.006)\end{array}$ & $\begin{array}{c}0.001 \\
(0.002)\end{array}$ & $\begin{array}{c}0.002 \\
(0.002)\end{array}$ & $\begin{array}{l}-0.001 \\
(0.001)\end{array}$ \\
\hline Male $\times$ Dad BA & $\begin{array}{l}-0.014 \\
(0.020)\end{array}$ & $\begin{array}{c}0.001 \\
(0.001)\end{array}$ & $\begin{array}{l}-0.001 \\
(0.005)\end{array}$ & $\begin{array}{c}0.002 \\
(0.001)\end{array}$ & $\begin{array}{c}0.002 \\
(0.001)\end{array}$ & $\begin{array}{c}0.000 \\
(0.001)\end{array}$ & $\begin{array}{l}-0.008 \\
(0.030)\end{array}$ & $\begin{array}{c}0.001 \\
(0.002)\end{array}$ & $\begin{array}{c}-0.007 \\
(0.007)\end{array}$ & $\begin{array}{c}0.002 \\
(0.002)\end{array}$ & $\begin{array}{c}0.002 \\
(0.002)\end{array}$ & $\begin{array}{c}0.001 \\
(0.001)\end{array}$ \\
\hline Male $\times$ Mom Immig & $\begin{array}{l}-0.011 \\
(0.035)\end{array}$ & $\begin{array}{l}-0.001 \\
(0.002)\end{array}$ & $\begin{array}{l}-0.005 \\
(0.008)\end{array}$ & $\begin{array}{l}-0.003 \\
(0.003)\end{array}$ & $\begin{array}{c}0.000 \\
(0.002)\end{array}$ & $\begin{array}{l}-0.001 \\
(0.001)\end{array}$ & $\begin{array}{l}-0.044 \\
(0.053)\end{array}$ & $\begin{array}{c}0.002 \\
(0.003)\end{array}$ & $\begin{array}{c}0.011 \\
(0.011)\end{array}$ & $\begin{array}{c}0.000 \\
(0.004)\end{array}$ & $\begin{array}{c}0.002 \\
(0.004)\end{array}$ & $\begin{array}{c}0.002 \\
(0.002)\end{array}$ \\
\hline Male $\times$ Dad Immig & $\begin{array}{c}0.006 \\
(0.032)\end{array}$ & $\begin{array}{l}-0.002 \\
(0.002)\end{array}$ & $\begin{array}{l}-0.000 \\
(0.008)\end{array}$ & $\begin{array}{c}0.002 \\
(0.002)\end{array}$ & $\begin{array}{c}0.000 \\
(0.002)\end{array}$ & $\begin{array}{c}0.002 \\
(0.001)\end{array}$ & $\begin{array}{c}0.064 \\
(0.051)\end{array}$ & $\begin{array}{c}0.000 \\
(0.003)\end{array}$ & $\begin{array}{l}-0.001 \\
(0.012)\end{array}$ & $\begin{array}{c}0.002 \\
(0.004)\end{array}$ & $\begin{array}{l}-0.001 \\
(0.003)\end{array}$ & $\begin{array}{l}-0.000 \\
(0.002)\end{array}$ \\
\hline Male $\times$ Married & $\begin{array}{c}0.008 \\
(0.012)\end{array}$ & $\begin{array}{l}-0.001 \\
(0.001)\end{array}$ & $\begin{array}{c}0.004 \\
(0.003)\end{array}$ & $\begin{array}{c}-0.002^{*} \\
(0.001)\end{array}$ & $\begin{array}{l}-0.001 \\
(0.001)\end{array}$ & $\begin{array}{c}-0.001^{* *} \\
(0.000)\end{array}$ & $\begin{array}{c}-0.001 \\
(0.021)\end{array}$ & $\begin{array}{c}0.000 \\
(0.001)\end{array}$ & $\begin{array}{c}0.004 \\
(0.005)\end{array}$ & $\begin{array}{l}-0.003 \\
(0.002)\end{array}$ & $\begin{array}{l}-0.001 \\
(0.002)\end{array}$ & $\begin{array}{l}-0.001 \\
(0.001)\end{array}$ \\
\hline $\mathrm{N}$ & 874,364 & 874,364 & 290,990 & 855,344 & 853,207 & 864,998 & 564,531 & 564,531 & 95,853 & 549,252 & 547,131 & 554,489 \\
\hline Mean of $Y$ & 10.757 & 0.044 & 0.306 & 0.047 & 0.043 & 0.011 & 10.835 & 0.040 & 0.271 & 0.043 & 0.039 & 0.011 \\
\hline Prob $>F$ & 0.483 & 0.643 & 0.641 & 0.029 & 0.092 & 0.626 & 0.516 & 0.857 & 0.707 & 0.374 & 0.874 & 0.458 \\
\hline
\end{tabular}

Standard errors in parentheses, clustered at the family level. ${ }^{*} p<0.1,{ }^{* *} p<0.05,{ }^{* * *} p<0.01$. F-test of whether all the male-interaction terms are equal to zero. The samples consist of individuals born from 1980-1995. Estimates from each column in each panel come from separate regressions. Check-ups measures the total number of check-ups at general practitioner, midwife, and specialist during pregnancy. Pregnancy complications is a binary indicator taking the value 1 if the mother is diagnosed with preeclampsia, gestational hypertension, or gestational diabetes mellitus during pregnancy. Smoke indicates whether the mother smoked during pregnancy and is observed for birth cohorts 1991-1995. Preterm indicates whether the child was born before 37 weeks of gestation. $L B W$ is an indicator for low birth weight, i.e. below 2,500 grams. Low Apgar indicates whether the child had a five minutes Apgar score below 7, which is medically considered a low score. All models control for year of birth dummies, month of birth dummies, birth order dummies, maternal age at birth (linear, squared, and cubed), and a constant. All OLS models additionally control for family size dummies and those variables of family environment that are interacted with the male dummy, and the FE models control for family fixed effects. 
Table A3

Educational Attainment at Age 27 by Birth Cohort: Male-Cohort-Family Environment Interactions

\begin{tabular}{|c|c|c|c|c|c|c|c|c|c|}
\hline & $\begin{array}{c}\text { Male } \\
(1)\end{array}$ & $\begin{array}{c}\text { Mom HS } \\
(2)\end{array}$ & $\begin{array}{c}\text { Mom BA } \\
(3)\end{array}$ & $\begin{array}{c}\text { Dad HS } \\
(4)\end{array}$ & $\begin{array}{c}\text { Dad BA } \\
(5)\end{array}$ & $\begin{array}{c}\text { Trad } 12 \\
(6)\end{array}$ & $\begin{array}{c}\text { Step } 12 \\
(7)\end{array}$ & $\begin{array}{l}\text { Mom } \\
\text { Immig } \\
(8)\end{array}$ & $\begin{array}{l}\text { Dad } \\
\text { Immig } \\
(9)\end{array}$ \\
\hline \multicolumn{10}{|c|}{ Panel A: Highest Completed Education (Months) } \\
\hline Male $\times 1966-70$ & $\begin{array}{c}-1.437^{* * *} \\
(0.427)\end{array}$ & $\begin{array}{c}-0.864^{* * *} \\
(0.297)\end{array}$ & $\begin{array}{c}-1.939^{* * *} \\
(0.437)\end{array}$ & $\begin{array}{c}2.636^{* * *} \\
(0.289)\end{array}$ & $\begin{array}{c}2.739^{* * *} \\
(0.452)\end{array}$ & $\begin{array}{c}0.053 \\
(0.416)\end{array}$ & $\begin{array}{c}0.728 \\
(0.658)\end{array}$ & $\begin{array}{c}1.801^{* *} \\
(0.858)\end{array}$ & $\begin{array}{l}1.607^{*} \\
(0.899)\end{array}$ \\
\hline Male $\times 1971-74$ & $\begin{array}{c}-2.379^{* * *} \\
(0.427)\end{array}$ & $\begin{array}{c}-1.133^{* * *} \\
(0.291)\end{array}$ & $\begin{array}{c}-2.803^{* * *} \\
(0.396)\end{array}$ & $\begin{array}{c}1.451^{* * *} \\
(0.293)\end{array}$ & $\begin{array}{c}0.946^{* *} \\
(0.427)\end{array}$ & $\begin{array}{c}0.423 \\
(0.405)\end{array}$ & $\begin{array}{c}0.022 \\
(0.625)\end{array}$ & $\begin{array}{c}1.856^{* *} \\
(0.812)\end{array}$ & $\begin{array}{l}0.913 \\
(0.816)\end{array}$ \\
\hline Male $\times 1975-78$ & $\begin{array}{c}-2.493^{* * *} \\
(0.449)\end{array}$ & $\begin{array}{c}-1.220^{* * *} \\
(0.306)\end{array}$ & $\begin{array}{c}-2.749^{* * *} \\
(0.396)\end{array}$ & $\begin{array}{l}0.510^{*} \\
(0.309)\end{array}$ & $\begin{array}{c}0.599 \\
(0.447)\end{array}$ & $\begin{array}{l}-0.033 \\
(0.420)\end{array}$ & $\begin{array}{c}-0.548 \\
(0.640)\end{array}$ & $\begin{array}{c}0.683 \\
(0.826)\end{array}$ & $\begin{array}{c}-1.558^{*} \\
(0.827)\end{array}$ \\
\hline Male $\times 1979-84$ & $\begin{array}{c}-3.677^{* * *} \\
(0.480)\end{array}$ & $\begin{array}{c}-1.247^{* * *} \\
(0.332)\end{array}$ & $\begin{array}{c}-2.597^{* * *} \\
(0.401)\end{array}$ & $\begin{array}{c}0.411 \\
(0.335)\end{array}$ & $\begin{array}{c}0.553 \\
(0.465)\end{array}$ & $\begin{array}{l}-0.569 \\
(0.444)\end{array}$ & $\begin{array}{l}-0.400 \\
(0.667)\end{array}$ & $\begin{array}{l}-1.015 \\
(0.841)\end{array}$ & $\begin{array}{c}-1.717^{* *} \\
(0.831)\end{array}$ \\
\hline \multicolumn{10}{|c|}{ Panel B: BA Degree } \\
\hline Male $\times 1966-70$ & $\begin{array}{c}-0.043^{* * *} \\
(0.006)\end{array}$ & $\begin{array}{c}-0.010^{* *} \\
(0.005)\end{array}$ & $\begin{array}{c}-0.049^{* * *} \\
(0.008)\end{array}$ & $\begin{array}{c}0.009^{* *} \\
(0.004)\end{array}$ & $\begin{array}{c}0.042^{* * *} \\
(0.008)\end{array}$ & $\begin{array}{c}-0.028^{* * *} \\
(0.006)\end{array}$ & $\begin{array}{c}0.006 \\
(0.008)\end{array}$ & $\begin{array}{c}0.018 \\
(0.013)\end{array}$ & $\begin{array}{l}0.023^{*} \\
(0.014)\end{array}$ \\
\hline Male $\times 1971-74$ & $\begin{array}{c}-0.043^{* * *} \\
(0.006)\end{array}$ & $\begin{array}{c}-0.029^{* * *} \\
(0.005)\end{array}$ & $\begin{array}{c}-0.075^{* * *} \\
(0.007)\end{array}$ & $\begin{array}{c}0.002 \\
(0.004)\end{array}$ & $\begin{array}{c}0.021^{* * *} * \\
(0.008)\end{array}$ & $\begin{array}{c}-0.039^{* * *} \\
(0.006)\end{array}$ & $\begin{array}{c}-0.010 \\
(0.009)\end{array}$ & $\begin{array}{c}0.039^{* * *} * \\
(0.013)\end{array}$ & $\begin{array}{c}0.033^{* *} \\
(0.013)\end{array}$ \\
\hline Male $\times 1975-78$ & $\begin{array}{c}-0.076^{* * *} \\
(0.007)\end{array}$ & $\begin{array}{c}-0.029^{* * *} \\
(0.005)\end{array}$ & $\begin{array}{c}-0.063^{* * *} \\
(0.007)\end{array}$ & $\begin{array}{c}-0.015^{* * *} \\
(0.005)\end{array}$ & $\begin{array}{c}0.019^{* *} \\
(0.008)\end{array}$ & $\begin{array}{c}-0.036^{* * *} \\
(0.007)\end{array}$ & $\begin{array}{l}-0.014 \\
(0.009)\end{array}$ & $\begin{array}{c}0.056^{* * * *} \\
(0.014)\end{array}$ & $\begin{array}{c}0.021 \\
(0.014)\end{array}$ \\
\hline Male $\times 1979-84$ & $\begin{array}{c}-0.097^{* * *} \\
(0.007)\end{array}$ & $\begin{array}{c}-0.032^{* * *} \\
(0.006)\end{array}$ & $\begin{array}{c}-0.056^{* * *} \\
(0.007)\end{array}$ & $\begin{array}{c}-0.017^{* * *} \\
(0.005)\end{array}$ & $\begin{array}{c}0.019 * * \\
(0.009)\end{array}$ & $\begin{array}{c}-0.048^{* * *} \\
(0.007)\end{array}$ & $\begin{array}{c}0.018^{*} \\
(0.010)\end{array}$ & $\begin{array}{c}0.046^{* * *} \\
(0.014)\end{array}$ & $\begin{array}{c}0.014 \\
(0.014)\end{array}$ \\
\hline
\end{tabular}

Standard errors in parentheses, clustered at the family level. ${ }^{*} p<0.1,{ }^{* *} p<0.05,{ }^{* * *} p<0.01$. The sample is the sibling sample with individuals born from 1966-1984. $N=764,792$. All estimates come from one regression as specified in equation (3), i.e. a regression interacting the male-family environment interactions as well as the family environment variables with birth cohort dummies. The model controls additionally for family fixed effects, year of birth dummies, month of birth dummies, birth order dummies, maternal age at birth (linear, squared, and cubed), two dummies for being observed at age 26 or 28 instead of at age 27, and a constant. The outcome in Panel A is highest completed education (in months) at age 27 with a mean of 154,707; the outcome in Panel B is BA graduate, indicating whether the person has at least a BA degree by age 27 with a mean of 0.231 . 
Table A4

Interactions between Mother's and Father's Education

\begin{tabular}{|c|c|c|c|c|c|c|}
\hline & \multicolumn{2}{|c|}{ - Grade 9 - } & \multicolumn{4}{|c|}{ - Age 27 - } \\
\hline & $\begin{array}{c}\text { On Time } \\
(1)\end{array}$ & $\begin{array}{l}\text { GPA } \\
(2)\end{array}$ & $\begin{array}{l}\text { Highest } \\
\text { Edu } \\
(3)\end{array}$ & $\begin{array}{l}\mathrm{BA} \\
(4)\end{array}$ & $\begin{array}{l}\text { Em- } \\
\text { ployed } \\
(5)\end{array}$ & $\begin{array}{c}\text { Earnings } \\
\text { Pct. } \\
(6)\end{array}$ \\
\hline Male & $\begin{array}{c}-0.110^{* * *} \\
(0.006)\end{array}$ & $\begin{array}{c}-0.312^{* * *} \\
(0.014)\end{array}$ & $\begin{array}{c}-3.670^{* * *} \\
(0.362)\end{array}$ & $\begin{array}{c}-0.090^{* * *} \\
(0.005)\end{array}$ & $\begin{array}{c}0.063^{* * *} \\
(0.005)\end{array}$ & $\begin{array}{c}0.032^{* * *} \\
(0.005)\end{array}$ \\
\hline Male $\times$ Mom HS & $\begin{array}{c}0.009 \\
(0.008)\end{array}$ & $\begin{array}{l}-0.009 \\
(0.018)\end{array}$ & $\begin{array}{c}-0.694^{*} \\
(0.412)\end{array}$ & $\begin{array}{c}-0.037^{* * *} \\
(0.007)\end{array}$ & $\begin{array}{c}-0.037^{* * *} \\
(0.006)\end{array}$ & $\begin{array}{c}-0.019^{* * *} \\
(0.006)\end{array}$ \\
\hline Male $\times$ Mom BA & $\begin{array}{c}0.003 \\
(0.010)\end{array}$ & $\begin{array}{l}-0.002 \\
(0.024)\end{array}$ & $\begin{array}{c}-2.267^{* * *} \\
(0.607)\end{array}$ & $\begin{array}{c}-0.097^{* * *} \\
(0.011)\end{array}$ & $\begin{array}{c}-0.026^{* * *} \\
(0.008)\end{array}$ & $\begin{array}{c}-0.029^{* * *} \\
(0.009)\end{array}$ \\
\hline Male $\times$ Dad HS & $\begin{array}{c}0.006 \\
(0.007)\end{array}$ & $\begin{array}{l}-0.001 \\
(0.017)\end{array}$ & $\begin{array}{c}1.111^{* * *} \\
(0.324)\end{array}$ & $\begin{array}{c}-0.024^{* * *} \\
(0.005)\end{array}$ & $\begin{array}{c}-0.024^{* * *} \\
(0.005)\end{array}$ & $\begin{array}{c}-0.020^{* * *} \\
(0.005)\end{array}$ \\
\hline Male $\times$ Dad BA & $\begin{array}{c}0.009 \\
(0.013)\end{array}$ & $\begin{array}{c}0.051 \\
(0.031)\end{array}$ & $\begin{array}{l}-0.098 \\
(0.727)\end{array}$ & $\begin{array}{c}-0.032^{* *} \\
(0.013)\end{array}$ & $\begin{array}{c}-0.029^{* * *} \\
(0.010)\end{array}$ & $\begin{array}{c}-0.051^{* * *} \\
(0.010)\end{array}$ \\
\hline Male $\times$ Mom Immig & $\begin{array}{c}0.027^{* * *} \\
(0.008)\end{array}$ & $\begin{array}{c}0.004 \\
(0.020)\end{array}$ & $\begin{array}{l}-0.238 \\
(0.615)\end{array}$ & $\begin{array}{c}0.051^{* * *} \\
(0.010)\end{array}$ & $\begin{array}{c}0.010 \\
(0.009)\end{array}$ & $\begin{array}{l}-0.008 \\
(0.009)\end{array}$ \\
\hline Male $\times$ Dad Immig & $\begin{array}{l}-0.012 \\
(0.008)\end{array}$ & $\begin{array}{c}0.009 \\
(0.019)\end{array}$ & $\begin{array}{c}-1.610^{* * *} \\
(0.608)\end{array}$ & $\begin{array}{l}0.017^{*} \\
(0.010)\end{array}$ & $\begin{array}{c}0.023^{* * *} \\
(0.009)\end{array}$ & $\begin{array}{l}-0.013 \\
(0.008)\end{array}$ \\
\hline Male $\times$ Married & $\begin{array}{l}0.006^{*} \\
(0.003)\end{array}$ & $\begin{array}{c}-0.016^{*} \\
(0.008)\end{array}$ & $\begin{array}{c}0.222 \\
(0.322)\end{array}$ & $\begin{array}{c}-0.019^{* * *} \\
(0.005)\end{array}$ & $\begin{array}{c}0.006 \\
(0.005)\end{array}$ & $\begin{array}{l}0.008^{*} \\
(0.004)\end{array}$ \\
\hline \multicolumn{7}{|c|}{ Parental Education-Interactions: } \\
\hline Male×Mom HS*Dad HS & $\begin{array}{c}-0.001 \\
(0.009)\end{array}$ & $\begin{array}{c}0.002 \\
(0.022)\end{array}$ & $\begin{array}{c}-0.873^{*} \\
(0.506)\end{array}$ & $\begin{array}{c}0.008 \\
(0.008)\end{array}$ & $\begin{array}{l}0.012^{*} \\
(0.007)\end{array}$ & $\begin{array}{c}0.001 \\
(0.007)\end{array}$ \\
\hline Male×Mom HS*Dad BA & $\begin{array}{c}0.014 \\
(0.016)\end{array}$ & $\begin{array}{c}0.022 \\
(0.037)\end{array}$ & $\begin{array}{c}0.096 \\
(0.920)\end{array}$ & $\begin{array}{c}0.039^{* *} \\
(0.017)\end{array}$ & $\begin{array}{c}0.014 \\
(0.012)\end{array}$ & $\begin{array}{c}0.000 \\
(0.013)\end{array}$ \\
\hline Male×Mom BA*Dad HS & $\begin{array}{c}0.015 \\
(0.012)\end{array}$ & $\begin{array}{c}0.035 \\
(0.028)\end{array}$ & $\begin{array}{l}-1.409^{*} \\
(0.720)\end{array}$ & $\begin{array}{l}0.025^{*} \\
(0.013)\end{array}$ & $\begin{array}{c}0.001 \\
(0.010)\end{array}$ & $\begin{array}{c}0.000 \\
(0.010)\end{array}$ \\
\hline Male×Mom BA*Dad BA & $\begin{array}{c}0.017 \\
(0.016) \\
\end{array}$ & $\begin{array}{c}0.008 \\
(0.038) \\
\end{array}$ & $\begin{array}{c}0.680 \\
(0.960)\end{array}$ & $\begin{array}{c}0.085^{* * *} \\
(0.018)\end{array}$ & $\begin{array}{l}-0.001 \\
(0.013)\end{array}$ & $\begin{array}{c}0.007 \\
(0.013)\end{array}$ \\
\hline $\mathrm{N}$ & 340,562 & 281,102 & 359,747 & 359,747 & 361,712 & 292,440 \\
\hline Mean of Y & 0.823 & 0.040 & 157.218 & 0.275 & 0.904 & 0.518 \\
\hline Prob $>F$ & 0.374 & 0.178 & 0.034 & 0.000 & 0.408 & 0.933 \\
\hline
\end{tabular}

Standard errors in parentheses, clustered at the family level. ${ }^{*} p<0.1,{ }^{* *} p<0.05,{ }^{* * *} p<0.01$. F-test of whether the additional Male $\times$ Mom Edu*Dad Edu interaction terms are jointly equal to zero. The sample consists of the sibling sample born from 1986-1995 for the two grade 9 outcomes and from 1973-1984 for the four age 27 outcomes. Grade 9 on time indicates whether the person completed grade 9 by age 16. GPA is an average of all grades given during grade 9 both from teacher assessment and final exams for all subjects and is standardized with mean zero and standard deviation of 1 by year of grade 9 completion for the total population. Highest completed education measures the length of highest completed education in months. BA graduate indicates whether the person has at least a BA degree. Employed takes the value one if the person has positive wage earnings or have employment as the main source of income including self-employment and zero otherwise. Earnings percentile measures the annual earnings percentile by gender and year of birth for those with positive labor earnings. All models control for family fixed effects, year of birth dummies, month of birth dummies, birth order dummies, maternal age at birth (linear, squared, and cubed), a constant, and two dummies for being observed at age 26 or 28 instead of at age 27 for the age 27 outcomes. 
Table A5

Interactions between Family Environment and Marital Status at birth

\begin{tabular}{|c|c|c|c|c|c|c|}
\hline & \multicolumn{2}{|c|}{ - Grade 9 - } & \multicolumn{4}{|c|}{ - Age 27 - } \\
\hline & $\begin{array}{c}\text { On Time } \\
(1)\end{array}$ & $\begin{array}{c}\text { GPA } \\
(2)\end{array}$ & $\begin{array}{c}\text { Highest } \\
\text { Edu } \\
(3)\end{array}$ & $\begin{array}{l}\text { BA } \\
(4)\end{array}$ & $\begin{array}{l}\text { Em- } \\
\text { ployed } \\
(5)\end{array}$ & $\begin{array}{c}\text { Earnings } \\
\text { Pct. } \\
(6)\end{array}$ \\
\hline Male & $\begin{array}{c}-0.107^{* * *} \\
(0.007)\end{array}$ & $\begin{array}{c}-0.316^{* * *} \\
(0.017)\end{array}$ & $\begin{array}{c}-2.286^{* * *} \\
(0.540)\end{array}$ & $\begin{array}{c}-0.065 * * * \\
(0.007)\end{array}$ & $\begin{array}{c}0.064^{* * *} \\
(0.009)\end{array}$ & $\begin{array}{c}0.028^{* * *} \\
(0.008)\end{array}$ \\
\hline Male $\times$ Mom HS & $\begin{array}{l}0.008 \\
(0.008)\end{array}$ & $\begin{array}{c}0.000 \\
(0.018)\end{array}$ & $\begin{array}{c}-3.558^{* * *} \\
(0.760)\end{array}$ & $\begin{array}{c}-0.060^{* * *} \\
(0.012)\end{array}$ & $\begin{array}{c}-0.034^{* * *} \\
(0.011)\end{array}$ & $\begin{array}{c}-0.024^{* *} \\
(0.010)\end{array}$ \\
\hline Male $\times$ Mom BA & $\begin{array}{c}0.013 \\
(0.008)\end{array}$ & $\begin{array}{c}0.028 \\
(0.020)\end{array}$ & $\begin{array}{c}-3.645^{* * *} \\
(0.881)\end{array}$ & $\begin{array}{c}-0.076^{* * *} \\
(0.015)\end{array}$ & $\begin{array}{c}-0.036^{* * *} \\
(0.012)\end{array}$ & $\begin{array}{c}-0.030^{* *} \\
(0.012)\end{array}$ \\
\hline Male $\times$ Dad HS & $\begin{array}{l}-0.001 \\
(0.007)\end{array}$ & $\begin{array}{c}0.000 \\
(0.017)\end{array}$ & $\begin{array}{c}0.440 \\
(0.690)\end{array}$ & $\begin{array}{c}-0.042^{* * *} \\
(0.010)\end{array}$ & $\begin{array}{l}-0.017^{*} \\
(0.010)\end{array}$ & $\begin{array}{l}-0.013 \\
(0.010)\end{array}$ \\
\hline Male $\times$ Dad BA & $\begin{array}{c}0.023^{* *} \\
(0.010)\end{array}$ & $\begin{array}{l}0.041^{*} \\
(0.023)\end{array}$ & $\begin{array}{l}-0.451 \\
(1.042)\end{array}$ & $\begin{array}{l}-0.025 \\
(0.018)\end{array}$ & $\begin{array}{l}-0.021 \\
(0.015)\end{array}$ & $\begin{array}{c}-0.035^{* *} \\
(0.014)\end{array}$ \\
\hline Male $\times$ Mom Immig & $\begin{array}{c}0.037 \\
(0.024)\end{array}$ & $\begin{array}{l}-0.047 \\
(0.055)\end{array}$ & $\begin{array}{l}-0.189 \\
(2.770)\end{array}$ & $\begin{array}{c}0.006 \\
(0.038)\end{array}$ & $\begin{array}{l}-0.017 \\
(0.034)\end{array}$ & $\begin{array}{l}-0.011 \\
(0.032)\end{array}$ \\
\hline Male $\times$ Dad Immig & $\begin{array}{l}-0.012 \\
(0.018)\end{array}$ & $\begin{array}{l}-0.009 \\
(0.043)\end{array}$ & $\begin{array}{c}-4.108^{* *} \\
(1.968)\end{array}$ & $\begin{array}{c}0.008 \\
(0.029)\end{array}$ & $\begin{array}{l}-0.008 \\
(0.030)\end{array}$ & $\begin{array}{c}0.010 \\
(0.029)\end{array}$ \\
\hline Male $\times$ Married & $\begin{array}{l}-0.001 \\
(0.009)\end{array}$ & $\begin{array}{l}-0.018 \\
(0.021)\end{array}$ & $\begin{array}{l}-1.123^{*} \\
(0.584)\end{array}$ & $\begin{array}{c}-0.055^{* * *} * \\
(0.008)\end{array}$ & $\begin{array}{c}0.003 \\
(0.009)\end{array}$ & $\begin{array}{c}0.012 \\
(0.008)\end{array}$ \\
\hline \multicolumn{7}{|c|}{ Marital Status at Birth-Interactions: } \\
\hline Male $\times$ Mom HS*Married & $\begin{array}{c}0.002 \\
(0.009)\end{array}$ & $\begin{array}{l}-0.009 \\
(0.021)\end{array}$ & $\begin{array}{c}2.589^{* * *} \\
(0.797)\end{array}$ & $\begin{array}{c}0.032^{* * *} \\
(0.012)\end{array}$ & $\begin{array}{c}0.006 \\
(0.011)\end{array}$ & $\begin{array}{c}0.005 \\
(0.011)\end{array}$ \\
\hline Male $\times$ Mom BA*Married & $\begin{array}{c}0.001 \\
(0.010)\end{array}$ & $\begin{array}{l}-0.014 \\
(0.024)\end{array}$ & $\begin{array}{c}0.939 \\
(0.931)\end{array}$ & $\begin{array}{c}0.013 \\
(0.016)\end{array}$ & $\begin{array}{c}0.009 \\
(0.013)\end{array}$ & $\begin{array}{c}0.004 \\
(0.013)\end{array}$ \\
\hline Male×Dad HS*Married & $\begin{array}{c}0.013 \\
(0.009)\end{array}$ & $\begin{array}{c}0.009 \\
(0.021)\end{array}$ & $\begin{array}{c}0.186 \\
(0.733)\end{array}$ & $\begin{array}{c}0.028^{* * *} \\
(0.011)\end{array}$ & $\begin{array}{l}-0.003 \\
(0.011)\end{array}$ & $\begin{array}{l}-0.008 \\
(0.010)\end{array}$ \\
\hline Male $\times$ Dad BA*Married & $\begin{array}{l}-0.004 \\
(0.011)\end{array}$ & $\begin{array}{c}0.016 \\
(0.026)\end{array}$ & $\begin{array}{l}1.236 \\
(1.098)\end{array}$ & $\begin{array}{c}0.047^{* *} \\
(0.019)\end{array}$ & $\begin{array}{l}-0.004 \\
(0.015)\end{array}$ & $\begin{array}{l}-0.013 \\
(0.015)\end{array}$ \\
\hline Male $\times$ Mom Immig*Married & $\begin{array}{l}-0.010 \\
(0.025)\end{array}$ & $\begin{array}{c}0.054 \\
(0.059)\end{array}$ & $\begin{array}{l}-0.191 \\
(2.842)\end{array}$ & $\begin{array}{c}0.048 \\
(0.040)\end{array}$ & $\begin{array}{c}0.027 \\
(0.035)\end{array}$ & $\begin{array}{c}0.005 \\
(0.033)\end{array}$ \\
\hline Male×Dad Immig*Married & $\begin{array}{c}0.001 \\
(0.020)\end{array}$ & $\begin{array}{c}0.021 \\
(0.048)\end{array}$ & $\begin{array}{c}2.753 \\
(2.070)\end{array}$ & $\begin{array}{c}0.008 \\
(0.031)\end{array}$ & $\begin{array}{c}0.034 \\
(0.031)\end{array}$ & $\begin{array}{l}-0.025 \\
(0.030) \\
\end{array}$ \\
\hline $\mathrm{N}$ & 340,562 & 281,102 & 359,747 & 359,747 & 361,712 & 292,440 \\
\hline Mean of Y & 0.823 & 0.040 & 157.218 & 0.275 & 0.904 & 0.518 \\
\hline Prob $>F$ & 0.448 & 0.906 & 0.016 & 0.000 & 0.813 & 0.922 \\
\hline
\end{tabular}

Standard errors in parentheses, clustered at the family level. ${ }^{*} p<0.1,{ }^{* *} p<0.05,{ }^{* * *} p<0.01$. F-test of whether the additional Male×Family Environment*Married interaction terms are jointly equal to zero. The sample consists of the sibling sample born from 1986-1995 for the two grade 9 outcomes and from 1973-1984 for the four age 27 outcomes. Grade 9 on time indicates whether the person completed grade 9 by age 16. GPA is an average of all grades given during grade 9 both from teacher assessment and final exams for all subjects and is standardized with mean zero and standard deviation of 1 by year of grade 9 completion for the total population. Highest completed education measures the length of highest completed education in months. BA graduate indicates whether the person has at least a BA degree. Employed takes the value one if the person has positive wage earnings or have employment as the main source of income including self-employment and zero otherwise. Earnings percentile measures the annual earnings percentile by gender and year of birth for those with positive labor earnings. All models control for family fixed effects, year of birth dummies, month of birth dummies, birth order dummies, maternal age at birth (linear, squared, and cubed), a constant, and two dummies for being observed at age 26 or 28 instead of at age 27 for the age 27 outcomes. 
Table A6

Robustness of Family Structure: Education and Labor Market Outcomes at Age 27

\begin{tabular}{|c|c|c|c|c|c|c|c|c|}
\hline & \multicolumn{2}{|c|}{ Compl Edu } & \multicolumn{2}{|c|}{$\mathrm{BA}$} & \multicolumn{2}{|c|}{ Employed } & \multicolumn{2}{|c|}{ Earnings Pct. } \\
\hline & (1) & $(2)$ & (3) & (4) & $(5)$ & $(6)$ & (7) & $(8)$ \\
\hline Male & $\begin{array}{c}-2.799^{* * *} \\
(0.370)\end{array}$ & $\begin{array}{c}-2.626^{* * *} \\
(0.436)\end{array}$ & $\begin{array}{c}-0.072^{* * *} \\
(0.005)\end{array}$ & $\begin{array}{c}-0.072^{* * *} \\
(0.006)\end{array}$ & $\begin{array}{c}0.070^{* * *} \\
(0.006)\end{array}$ & $\begin{array}{c}0.067^{* * *} \\
(0.007)\end{array}$ & $\begin{array}{c}0.036^{* * *} \\
(0.005)\end{array}$ & $\begin{array}{c}0.034^{* * *} \\
(0.006)\end{array}$ \\
\hline Male $\times$ Mom HS & $\begin{array}{c}-1.211^{* * *} \\
(0.230)\end{array}$ & $\begin{array}{c}-1.204^{* * *} \\
(0.242)\end{array}$ & $\begin{array}{c}-0.030^{* * *} \\
(0.004)\end{array}$ & $\begin{array}{c}-0.029^{* * *} \\
(0.004)\end{array}$ & $\begin{array}{c}-0.028^{* * *} \\
(0.003)\end{array}$ & $\begin{array}{c}-0.026^{* * *} \\
(0.003)\end{array}$ & $\begin{array}{c}-0.018^{* * *} \\
(0.003)\end{array}$ & $\begin{array}{c}-0.020^{* * *} \\
(0.003)\end{array}$ \\
\hline Male $\times$ Mom BA & $\begin{array}{c}-2.859^{* * *} \\
(0.285)\end{array}$ & $\begin{array}{c}-2.844^{* * *} \\
(0.299)\end{array}$ & $\begin{array}{c}-0.065^{* * *} \\
(0.005)\end{array}$ & $\begin{array}{c}-0.064^{* * *} \\
(0.006)\end{array}$ & $\begin{array}{c}-0.027^{* * *} \\
(0.004)\end{array}$ & $\begin{array}{c}-0.026^{* * *} \\
(0.004)\end{array}$ & $\begin{array}{c}-0.027^{* * *} \\
(0.004)\end{array}$ & $\begin{array}{c}-0.028^{* * *} \\
(0.004)\end{array}$ \\
\hline Male $\times$ Dad HS & $\begin{array}{c}0.606^{* * *} \\
(0.232)\end{array}$ & $\begin{array}{c}0.359 \\
(0.246)\end{array}$ & $\begin{array}{c}-0.017^{* * *} \\
(0.004)\end{array}$ & $\begin{array}{c}-0.018^{* * *} \\
(0.004)\end{array}$ & $\begin{array}{c}-0.019^{* * *} \\
(0.003)\end{array}$ & $\begin{array}{c}-0.020^{* * *} \\
(0.003)\end{array}$ & $\begin{array}{c}-0.020^{* * *} \\
(0.003)\end{array}$ & $\begin{array}{c}-0.021^{* * *} \\
(0.003)\end{array}$ \\
\hline Male $\times$ Dad BA & $\begin{array}{c}0.670^{* *} \\
(0.328)\end{array}$ & $\begin{array}{c}0.549 \\
(0.346)\end{array}$ & $\begin{array}{c}0.019^{* * *} \\
(0.006)\end{array}$ & $\begin{array}{c}0.022^{* * *} \\
(0.006)\end{array}$ & $\begin{array}{c}-0.024^{* * *} \\
(0.004)\end{array}$ & $\begin{array}{c}-0.024^{* * *} \\
(0.005)\end{array}$ & $\begin{array}{c}-0.047^{* * *} \\
(0.005)\end{array}$ & $\begin{array}{c}-0.049^{* * *} \\
(0.005)\end{array}$ \\
\hline Male $\times$ Mom Immig & $\begin{array}{l}-0.226 \\
(0.615)\end{array}$ & $\begin{array}{l}-0.182 \\
(0.655)\end{array}$ & $\begin{array}{c}0.051^{* * *} \\
(0.010)\end{array}$ & $\begin{array}{c}0.055^{* * *} \\
(0.011)\end{array}$ & $\begin{array}{c}0.012 \\
(0.009)\end{array}$ & $\begin{array}{c}0.014 \\
(0.009)\end{array}$ & $\begin{array}{l}-0.007 \\
(0.009)\end{array}$ & $\begin{array}{l}-0.009 \\
(0.009)\end{array}$ \\
\hline Male $\times$ Dad Immig & $\begin{array}{c}-1.664^{* * *} \\
(0.608)\end{array}$ & $\begin{array}{c}-1.799^{* * *} \\
(0.644)\end{array}$ & $\begin{array}{c}0.015 \\
(0.010)\end{array}$ & $\begin{array}{c}0.014 \\
(0.011)\end{array}$ & $\begin{array}{c}0.024^{* * *} \\
(0.009)\end{array}$ & $\begin{array}{c}0.026^{* * *} \\
(0.009)\end{array}$ & $\begin{array}{l}-0.012 \\
(0.008)\end{array}$ & $\begin{array}{l}-0.009 \\
(0.009)\end{array}$ \\
\hline Male×Trad 12 & & $\begin{array}{l}-0.501 \\
(0.417)\end{array}$ & & $\begin{array}{c}-0.052^{* * *} \\
(0.006)\end{array}$ & & $\begin{array}{l}-0.004 \\
(0.006)\end{array}$ & & $\begin{array}{c}0.007 \\
(0.006)\end{array}$ \\
\hline Male $\times$ Step 12 & & $\begin{array}{l}-0.771 \\
(0.637)\end{array}$ & & $\begin{array}{l}-0.011 \\
(0.009)\end{array}$ & & $\begin{array}{c}0.010 \\
(0.009)\end{array}$ & & $\begin{array}{c}0.006 \\
(0.009)\end{array}$ \\
\hline $\begin{array}{l}\text { Male } \times \text { Trad } 12 \\
\text { Oldest } \\
\text { Male } \times \text { Step } 12 \\
\text { Oldest }\end{array}$ & $\begin{array}{l}-0.504 \\
(0.350) \\
-0.618 \\
(0.540)\end{array}$ & & $\begin{array}{c}-0.048^{* * *} \\
(0.005) \\
-0.005 \\
(0.008)\end{array}$ & & $\begin{array}{c}-0.005 \\
(0.005) \\
0.010 \\
(0.008)\end{array}$ & & $\begin{array}{c}0.004 \\
(0.005) \\
-0.002 \\
(0.008)\end{array}$ & \\
\hline $\mathrm{N}$ & 359,747 & 321,802 & 359,747 & 321,802 & 361,712 & 323,469 & 292,440 & 263,241 \\
\hline Mean of $Y$ & 157.218 & 158.109 & 0.275 & 0.284 & 0.904 & 0.908 & 0.518 & 0.520 \\
\hline $\begin{array}{l}\text { Sample: } \\
\text { All Siblings } \\
\text { Only Same FS12 }\end{array}$ & $\mathrm{X}$ & X & $\mathrm{X}$ & X & $\mathrm{X}$ & X & $\mathrm{X}$ & $\mathrm{X}$ \\
\hline
\end{tabular}

Standard errors in parentheses, clustered at the family level. ${ }^{*} p<0.1,{ }^{* *} p<0.05,{ }^{* * *} p<0.01$. The sample consists of the sibling sample born from 1973-1984. The sample consists of biological siblings born from 1973-1984. The All Siblings sample tests the robustness of the main results by using family structure at age 12 of the oldest child instead of the youngest. The sample of Only Same FS12 tests the robustness of the main results by only using the sample of families in which children experience the same family structure at age 12. Highest completed education measures the length of highest completed education in months. BA graduate indicates whether the person has at least a BA degree. Employed takes the value one if the person has positive wage earnings or have employment as the main source of income including self-employment and zero otherwise. Earnings percentile measures the annual earnings percentile by gender and year of birth for those with positive labor earnings. All models control for family fixed effects, year of birth dummies, month of birth dummies, birth order dummies, maternal age at birth (linear, squared, and cubed), two dummies for being observed at age 26 or 28 instead of at age 27 , and a constant. 
Table A7

Total Population vs Siblings: Grade 9

\begin{tabular}{|c|c|c|c|c|c|c|c|c|c|c|c|c|}
\hline Dependent Var. & $(1)$ & $(2)$ & $\begin{array}{l}\text { Grade } 9 \\
(3)\end{array}$ & n Time & $(5)$ & $(6)$ & $(7)$ & (8) & (9) $\mathrm{G}$ & A & $(11)$ & $(12)$ \\
\hline $\begin{array}{l}\text { Panel A } \\
\text { Male }\end{array}$ & $\begin{array}{c}-0.092^{* * *} \\
(0.001)\end{array}$ & $\begin{array}{c}-0.097^{* * *} \\
(0.004)\end{array}$ & $\begin{array}{c}-0.087^{* * *} \\
(0.001)\end{array}$ & $\begin{array}{c}-0.085^{* * *} \\
(0.002)\end{array}$ & $\begin{array}{c}-0.088^{* * *} \\
(0.001)\end{array}$ & $\begin{array}{c}-0.089^{* * *} \\
(0.002)\end{array}$ & $\begin{array}{c}-0.295^{* * *} \\
(0.003)\end{array}$ & $\begin{array}{c}-0.301^{* * *} \\
(0.010)\end{array}$ & $\begin{array}{c}-0.308^{* * *} \\
(0.004)\end{array}$ & $\begin{array}{c}-0.315^{* * *} \\
(0.007)\end{array}$ & $\begin{array}{c}-0.302^{* * *} \\
(0.004)\end{array}$ & $\begin{array}{c}-0.308^{* * *} \\
(0.004)\end{array}$ \\
\hline $\begin{array}{l}\text { Panel B } \\
\text { Male } \\
\text { Male } \times \text { Mom HS } \\
\text { Male } \times \text { Mom BA } \\
\text { Male } \times \text { Dad HS } \\
\text { Male } \times \text { Dad BA } \\
\text { Male } \times \text { Mom Immig } \\
\text { Male } \times \text { Dad Immig } \\
\text { Male } \times \text { Married }\end{array}$ & $\begin{array}{c}-0.114^{* * *} \\
(0.003) \\
0.007^{* * *} \\
(0.002) \\
0.010^{* * *} \\
(0.003) \\
0.009^{* * *} \\
(0.002) \\
0.026^{* * *} \\
(0.003) \\
0.019^{* * *} \\
(0.005) \\
-0.002 \\
(0.005) \\
0.010^{* * *} \\
(0.002)\end{array}$ & $\begin{array}{c}-0.106^{* * *} \\
(0.009) \\
-0.012 \\
(0.009) \\
-0.003 \\
(0.010) \\
0.003 \\
(0.008) \\
0.033^{* * *} \\
(0.011) \\
0.008 \\
(0.016) \\
0.011 \\
(0.016) \\
0.017^{* *} \\
(0.008)\end{array}$ & $\begin{array}{c}-0.114^{* * *} \\
(0.004) \\
0.010^{* * *} \\
(0.003) \\
0.010^{* * *} \\
(0.004) \\
0.009^{* * *} \\
(0.003) \\
0.028^{* * *} \\
(0.004) \\
0.020^{* * *} \\
(0.007) \\
-0.005 \\
(0.007) \\
0.010^{* * *} \\
(0.003)\end{array}$ & $\begin{array}{c}-0.117^{* * *} \\
(0.006) \\
0.010^{*} \\
(0.005) \\
0.005 \\
(0.006) \\
0.011^{* *} \\
(0.005) \\
0.041^{* * *} \\
(0.007) \\
0.016 \\
(0.013) \\
0.001 \\
(0.012) \\
0.014^{* * *} \\
(0.004)\end{array}$ & $\begin{array}{c}-0.111^{* * *} \\
(0.005) \\
0.010^{* *} \\
(0.004) \\
0.013^{* * *} \\
(0.004) \\
0.008^{* *} \\
(0.004) \\
0.018^{* * *} \\
(0.005) \\
0.025^{* * *} \\
(0.008) \\
-0.012 \\
(0.008) \\
0.007^{* *} \\
(0.003)\end{array}$ & $\begin{array}{c}-0.111^{* * *} \\
(0.005) \\
0.009^{* *} \\
(0.004) \\
0.013^{* * *} \\
(0.005) \\
0.008^{* *} \\
(0.004) \\
0.018^{* * *} \\
(0.005) \\
0.027^{* * *} \\
(0.008) \\
-0.012 \\
(0.008) \\
0.006 * \\
(0.003)\end{array}$ & $\begin{array}{c}-0.273^{* * *} \\
(0.007) \\
-0.027^{* * *} \\
(0.006) \\
-0.022^{* * *} \\
(0.007) \\
-0.017^{* * *} \\
(0.006) \\
0.027^{* * *} \\
(0.008) \\
0.014 \\
(0.014) \\
0.014 \\
(0.013) \\
-0.019 * * * \\
(0.005)\end{array}$ & $\begin{array}{c}-0.258^{* * *} \\
(0.023) \\
-0.048^{* *} \\
(0.023) \\
-0.067^{* *} \\
(0.027) \\
-0.009 \\
(0.023) \\
0.040 \\
(0.030) \\
0.024 \\
(0.045) \\
0.055 \\
(0.042) \\
-0.038^{* *} \\
(0.020)\end{array}$ & $\begin{array}{c}-0.299 * * * \\
(0.010) \\
-0.014 \\
(0.009) \\
-0.003 \\
(0.010) \\
-0.014 \\
(0.009) \\
0.029^{* * *} \\
(0.011) \\
0.010 \\
(0.020) \\
0.014 \\
(0.019) \\
-0.015 * \\
(0.008)\end{array}$ & $\begin{array}{c}-0.289^{* * *} \\
(0.018) \\
-0.017 \\
(0.017) \\
-0.019 \\
(0.018) \\
-0.029^{*} \\
(0.017) \\
0.010 \\
(0.020) \\
-0.010 \\
(0.037) \\
0.007 \\
(0.034) \\
-0.017 \\
(0.013)\end{array}$ & $\begin{array}{c}-0.306^{* * *} \\
(0.011) \\
-0.011 \\
(0.010) \\
0.009 \\
(0.011) \\
-0.002 \\
(0.010) \\
0.045^{* * *} \\
(0.012) \\
0.017 \\
(0.021) \\
0.017 \\
(0.020) \\
-0.013 \\
(0.008)\end{array}$ & $\begin{array}{c}-0.317^{* * *} \\
(0.011) \\
-0.006 \\
(0.010) \\
0.018 \\
(0.011) \\
0.006 \\
(0.010) \\
0.052^{* * *} \\
(0.012) \\
0.004 \\
(0.020) \\
0.010 \\
(0.019) \\
-0.015^{*} \\
(0.008)\end{array}$ \\
\hline $\begin{array}{l}\mathrm{N} \\
\text { Mean of Y }\end{array}$ & $\begin{array}{c}585,381 \\
0.815\end{array}$ & $\begin{array}{c}43,632 \\
0.793\end{array}$ & $\begin{array}{c}340,562 \\
0.823\end{array}$ & $\begin{array}{c}144,672 \\
0.826\end{array}$ & $\begin{array}{c}195,890 \\
0.821\end{array}$ & $\begin{array}{c}340,562 \\
0.823\end{array}$ & $\begin{array}{c}513,762 \\
-0.005\end{array}$ & $\begin{array}{c}37,664 \\
0.050\end{array}$ & $\begin{array}{c}281,102 \\
0.040\end{array}$ & $\begin{array}{c}119,549 \\
0.058\end{array}$ & $\begin{array}{c}161,553 \\
0.027\end{array}$ & $\begin{array}{c}281,102 \\
0.040\end{array}$ \\
\hline $\begin{array}{l}\text { Sample: } \\
\text { Total Population } \\
\text { One-Child Families } \\
\text { Sibling Sample: } \\
\text { All Sibs } \\
\text { Same Sex Sibs } \\
\text { Mixed Sex Sibs } \\
\text { Estimation: } \\
\text { OLS } \\
\text { FE }\end{array}$ & $\mathrm{X}$ & $\mathrm{X}$ & $\mathrm{X}$ & $\mathrm{X}$ & $\begin{array}{l}X \\
X\end{array}$ & $\mathrm{X}$ & $\mathrm{X}$ & $\mathrm{X}$ & $\mathrm{X}$ & $\mathrm{X}$ & $\begin{array}{l}X \\
X\end{array}$ & $\begin{array}{l}\mathrm{X} \\
\mathrm{X}\end{array}$ \\
\hline
\end{tabular}


Table A8

Total Population vs Siblings: Age 27



